\title{
The participation of Australian Indigenous students in higher education: a scoping review of empirical research, 2000-2016
}

\author{
Jennifer Gore ${ }^{1} \cdot$ Sally Patfield $^{1} \cdot$ Leanne Fray $^{1}$ • \\ Kathryn Holmes ${ }^{2} \cdot$ Maree Gruppetta $^{3}$. \\ Adam Lloyd ${ }^{1} \cdot$ Maxwell Smith $^{1}$. Treesa Heath ${ }^{1}$
}

Received: 17 November 2016/ Accepted: 4 May 2017/Published online: 29 May 2017

(C) The Author(s) 2017. This article is an open access publication

\begin{abstract}
While access to higher education has increased for Indigenous Australians, participation and completion rates remain lower than those of nonIndigenous Australians. A sound evidence base is needed to ground equity initiatives if they are to address the specific needs of Indigenous students. This paper presents the results of a scoping review of empirical research focusing on the participation of Indigenous students in higher education. The purpose of the scoping review was to synthesise empirical research on aspirations for, and barriers and enablers to, higher education that were published between 2000 and $2016(n=57)$, and identify areas where further research is needed. Despite a recent increase in research on this topic, relatively little attention has been paid to Indigenous students' aspirations while they are at school. We argue that future research should take account of school students' aspirations for higher education, including primary school students; the similitude of barriers and enablers across the student life cycle; differences within Indigenous community and among Indigenous students; and, the insights emerging from Indigenous methodologies and scholarship.
\end{abstract}

Keywords Aspirations · Higher education · Indigenous students

Jennifer Gore

jenny.gore@newcastle.edu.au

1 School of Education, University of Newcastle, Callaghan, NSW, Australia

2 School of Education, Western Sydney University, Penrith, NSW, Australia

3 Wollotuka Institute, University of Newcastle, Callaghan, NSW, Australia 


\section{Introduction}

It is widely acknowledged that the higher education sector ${ }^{1}$ has a crucial role to play in reducing disadvantage experienced by Indigenous Australians through improving employment, economic, and health outcomes (Behrendt et al. 2012; Pechenkina and Anderson 2011; Pechenkina et al. 2011). The ninth annual Closing the Gap report released by the Australian Federal Government, for example, has drawn attention to a strong relationship between higher education and employment, with comparable workforce outcomes for Indigenous and non-Indigenous Australians with a Bachelor-level degree or higher (Commonwealth of Australia 2017). This report highlighted that as the level of education increases along the continuum from secondary school, to vocational education, to a university degree, the employment gap between Indigenous and non-Indigenous Australians declines (Commonwealth of Australia 2017). However, despite an increase in the number of Indigenous students enrolling in higher education in recent years, the proportion of Indigenous students at university remains significantly lower than non-Indigenous students (Behrendt et al. 2012; Bennett et al. 2015). In addition, while students in other targeted equity groups are not markedly less likely to complete their degree when they do enrol in university, Indigenous students experience high rates of attrition (Bennett et al. 2015).

Within the Australian higher education sector, although policies to widen participation have a long history (Gale and Parker 2013), a focus on students from underrepresented groups intensified in response to the 2008 Review of Australian Higher Education, commonly referred to as the Bradley Review (Bradley et al. 2008). In this review, Indigenous students were identified as one of the most seriously underrepresented groups in universities, together with students from low socioeconomic status backgrounds and those from regional and remote areas (Bradley et al. 2008). In 2012, the Review of Higher Education Access and Outcomes for Aboriginal and Torres Strait Islander People (Behrendt et al. 2012) examined the role of higher education in reducing the economic disadvantage experienced by Indigenous Australians. The Behrendt Report called for increased research in this area, given Indigenous students' significantly lower rates of access, retention, and completion (Behrendt et al. 2012).

In order to establish an evidence base for future research, the purpose of this paper is to bring together and summarise the empirical research that has been conducted in relation to the participation of Indigenous students in the Australian higher education sector. The Behrendt Report was critical in highlighting the specific needs of Indigenous Australians in higher education, who have often been inappropriately characterised as a sub-group within the broader category of low socioeconomic status and/or as one of a number of minority ethnic groups (Gale and Parker 2013). However, there has not been a comprehensive review of research in this field. This paper contributes a rigorous review of empirical studies related to

\footnotetext{
${ }^{1}$ Higher education in this paper refers to university education leading to an undergraduate award (Commonwealth of Australia 2012), excluding vocational education and training, and other tertiary education providers.
} 
current equity policy concerns with access, participation, retention, and completion rates for Indigenous students.

\section{Methods}

A scoping review methodology was chosen as a framework to map and explore relevant empirical studies, drawing on the approach developed by Arksey and O'Malley (2005). While systematic reviews are typically designed to answer a specific question about a population, the aim of a scoping review is to map what kinds of studies have been conducted, how they have been conducted, and what they have found. A scoping review therefore provides a "snapshot of a particular topic area" (Booth et al. 2012, p. 19), charting rather than evaluating studies conducted during the time period identified for the review (Arksey and O'Malley 2005; Tricco et al. 2016). Scoping reviews "vary in scope from general accounts of the literature to studies that are just short of systematic reviews" (Anderson et al. 2008, para 42). Our review is positioned towards the systematic review end of this continuum, providing more rather than less information about each of the studies, in an attempt to enhance the value of the review for future research in the field.

While there is some variation in how scoping reviews are conducted (Pham et al. 2014), four common purposes are (1) examining the extent, range, and nature of research in relation to a topic; (2) ascertaining the value of carrying out a systematic review; (3) summarising and disseminating findings; and, (4) identifying gaps in the extant literature (Arksey and O'Malley 2005). In this paper, our primary interests were mapping, summarising, and identifying gaps in, the extant literature. Our broad research question was 'What empirical studies have been published between 2000 and 2016 that provide data on the participation of Australian Indigenous students in higher education?' Given the equity policy focus on issues of access, participation, retention, and completion and the resources available for this project, we narrowed the substantive focus to five key areas pertaining to the participation of Indigenous Australians in higher education: educational and occupational aspirations; enablers to pursuing aspirations and accessing higher education; barriers to pursing aspirations and accessing higher education; enablers of participation, retention, and completion; and, barriers to participation, retention, and completion.

These five key areas acted as the primary inclusion criteria for the review, which were set a priori of the review process. The other inclusion criteria were empirical studies; conducted in Australia; and, published between 1 January 2000 and 31 March 2016, a date range encompassing both the Bradley Review and the Behrendt Report. Peer-reviewed journal articles and 'grey literature' (see Lefebvre et al. 2008) that specifically related to one or more of the five key areas of interest were included. Papers were excluded from the analysis if the methodology was not explicitly stated. Grey literature was limited to reports with a robust, clearly stated methodology from higher education institutions, government agencies, and other similar education and/or employment organisations.

A three-step approach was utilised as a framework for identifying the corpus of relevant literature. The first step involved a search of relevant databases, namely 
EBSCO Megafile Premier, ERIC, Informit Database Collections, and Google Scholar. These databases were chosen to provide wide-ranging coverage of the field of education research, with an important Australian focus specifically supplied by the Informit Database Collection. In order to locate all potentially relevant articles, search terms used at this stage were 'Indigenous' and/or 'Aboriginal and Torres Strait Islander', together with 'aspiration', 'student', 'career', 'university' and/or 'higher education', and 'barrier' and/or 'enabler'. This search yielded 179 publications.

Second, we conducted a manual journal search in those journals yielding three or more articles in the first step. These journals were the Australian Journal of Career Development, the Australian Journal of Education, The Australian Journal of Indigenous Education, and Higher Education Research and Development. No new articles were identified during this step.

Third, a reference list search was undertaken using those publications found in the first two steps, producing 23 new articles. A large degree of saturation occurred during the final two steps, wherein articles obtained during the first step began to appear numerous times in these final two searches. At the conclusion of this search process, 202 articles had been located. Next, all articles were uploaded into a single EndNote file and duplicates removed, yielding 153 articles. These articles were then read, and culled if they did not directly address one or more of the five key areas, a process which also took into account the inclusion and exclusion criteria.

Finally, given that scoping reviews should be reflexive rather than linear (Arksey and O'Malley 2005), an additional search was carried out several months later to ensure that the literature was covered in a comprehensive way. This process mirrored steps 1-3 above, and two additional articles were identified.

As a result of this entire process, 57 articles were included in the final scoping review, as detailed in Fig. 1. In order to synthesise the 57 articles, both quantitative and qualitative analyses were undertaken. Quantitative analysis involved frequency counts for year of publication, publication source, methodological approach, sample, and focus. Qualitative analysis, using NVivo 11 software, involved deductive coding of the articles, aligning with the five key areas, in order to identify major themes.

\section{Results}

\section{Descriptive overview}

A key step in the scoping review process is 'charting' the data (Arksey and O'Malley 2005). A comprehensive overview, providing the author(s), publication, sample, data sources, and thematic alignment of the 57 articles, is provided in Appendix Table 1. A brief description of the technical properties of the articles is provided below.

- Year of publication The scoping review included articles published from January 2000 up to and including March 2016. Substantially more articles were 


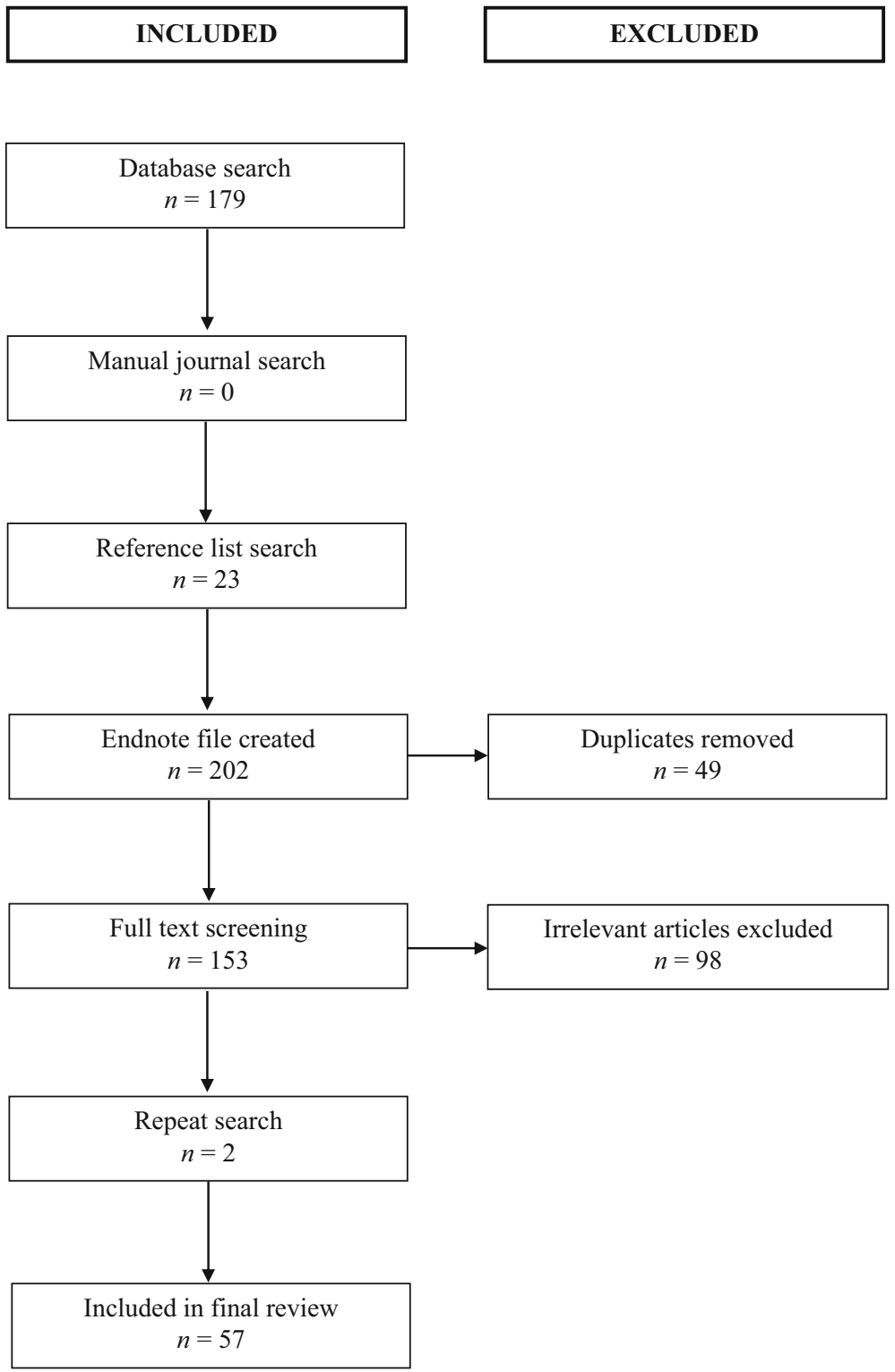

Fig. 1 The scoping review process

published during the latter half of the period, 2008-2016 $(n=43)$, encompassing the Bradley Review and Behrendt Report, compared with the earlier period, 2000-2007 ( $n=14)$. The most frequent year of publication was $2014(n=9)$, closely followed by $2015(n=8)$ and $2013(n=7)$.

- Publication source Publications were sourced from both journals and published reports. The most prevalent publication source was The Australian Journal of 
Indigenous Education $(n=16)$. This was followed by the journal, Higher Education Research and Development $(n=4)$. A number of journals yielded two articles: Australian Journal of Teacher Education, Australian Psychologist, Contemporary Issues in Education Research, Contemporary Nurse, the International Journal of Higher Education, and the Journal of Youth Studies. All other publication sources included in the review provided one article only.

- Methodological approaches The dominant methodology used within the reported publications was qualitative $(n=36)$, followed by mixed methods $(n=11)$, and quantitative $(n=10)$.

- Sample The majority of publications were situated within post-secondary and/or higher education contexts $(n=39)$, with the research sampling current and former university students, staff members, and other stakeholders. A smaller number of publications focused on Indigenous young people, and Indigenous students currently enrolled in primary and/or secondary school $(n=20)$. Two publications covered both higher education and schooling, and are therefore included in both of these samples. One study sampled Indigenous mothers in relation to their own and their children's aspirations. A small number of publications at the primary/secondary school level also incorporated the viewpoint of others, such as parents, teachers, careers advisors, and community stakeholders $(n=3)$.

- Focus The majority of publications had an explicit focus on higher education $(n=39)$. Of the other 18 publications, higher education was included as one of many possible post-secondary pathways for students, inclusive of vocational education and employment. This breadth was most prevalent in studies that investigated students' aspirations; of these articles, most did not explicitly focus on higher education $(n=14)$. In other instances, enablers and barriers to accessing higher education were closely entwined with enablers and barriers to students pursuing their post-school aspirations more broadly, which was taken into account in the thematic analysis below.

- Thematic alignment Using the five identified key areas, articles were identified in relation to the aspirations of Indigenous Australians $(n=15)$; enablers to pursuing aspirations and accessing higher education $(n=22)$; barriers to pursuing aspirations and accessing higher education $(n=21)$; enablers of participation, retention, and completion $(n=30)$; and, barriers to participation, retention, and completion $(n=27)$. Articles were counted more than once if relevant to multiple themes.

\section{Thematic overview}

This section is organised thematically by the five key areas, or 'primary units of analysis' (Arksey and O'Malley 2005), that underpinned the scoping review. 


\section{Aspirations}

Fifteen publications related specifically to the aspirations of Indigenous Australians. While the focus of the scoping review was Indigenous students, some studies sampled Indigenous young people who were not necessarily or explicitly stated as being enrolled in school; this research was incorporated in the review as the sample was nevertheless based on a similar age range of participants. Only one study explicitly concentrated on higher education, with the vast majority of articles focusing on post-school aspirations more generally, inclusive of higher education as one potential post-secondary avenue.

Educational aspirations There is clear consensus that Indigenous young people hold aspirations to complete secondary school (Craven et al. 2005; Godfrey et al. 2001; Harwood et al. 2015). However, they are more likely than their nonIndigenous peers to want to depart school earlier (Craven and Marsh 2004; Craven et al. 2005; De Bortoli and Cresswell 2004) and to plan to complete no further education past high school (De Bortoli and Cresswell 2004). Studies conducted at the secondary school level revealed that Indigenous students are less likely to aspire to university in comparison to non-Indigenous students (Craven et al. 2005; De Bortoli and Cresswell 2004). Importantly, it was also found that many Indigenous students do aim to go to university and attain a higher education (Craven and Marsh 2004; Craven et al. 2005; Gale et al. 2013; Godfrey et al. 2001; Harwood et al. 2015; Nelson and Hay 2010; Walker et al. 2008). Educational aspirations are also framed more generally by Indigenous students and their parents as the desire to receive 'a good education' (Lette et al. 2009; Walker et al. 2008).

Additionally, this relatively small body of research shows that a higher percentage of Indigenous students desire to commence Technical and Further Education (TAFE) or an apprenticeship after school, in comparison with their nonIndigenous peers (Craven and Marsh 2004; Craven et al. 2005; De Bortoli and Cresswell 2004; Mission Australia 2014). Large numbers of Indigenous students have also articulated a desire to obtain employment after secondary school (Craven and Marsh 2004; Craven et al. 2005). In particular, in one of the largest analyses to date which sampled school students from three Australian states, the majority of Indigenous students aspired to secure a job, in comparison to the majority of nonIndigenous students who aimed to go to university (Craven et al. 2005).

Differences among Indigenous students were also reported, based on sex and locality. In relation to sex, De Bortoli and Cresswell (2004) identified that a significantly higher percentage of Indigenous females aspired to complete their Year 12 studies in comparison to Indigenous males. Similarly, Sikora and Biddle (2015) observed that Indigenous males were less likely to plan to pursue university studies. Regarding geographic location, Craven et al. (2005) observed that some Indigenous students in rural locations felt constrained by their locality, in contrast to those from urban areas. 
Occupational aspirations In several studies, Indigenous school students nominated specific occupational aspirations, spanning the gamut of different professions such as teaching, law, medicine, nursing, hairdressing, child care, mechanics, defence, sport, and performing arts (Craven et al. 2005; Nelson and Hay 2010; Senior and Chenhall 2012; Sikora and Biddle 2015; Walker et al. 2008). However, in comparison to their non-Indigenous peers, Indigenous students have been found to be less likely to identify a career that requires a university qualification (Craven et al. 2005). In relation to sex, studies have found Indigenous females to be more oriented towards professional and 'caring' occupations than males (Sikora and Biddle 2015) and Indigenous males more likely than females to desire sports-based and semi-professional careers, with similar differences existing for non-Indigenous students (Craven et al. 2005; Sikora and Biddle 2015). Two separate studies have also pointed to Indigenous females aspiring towards more prestigious occupations than their male counterparts, a gendered pattern also seen for non-Indigenous students (Gale et al. 2013; Sikora and Biddle 2015).

Life aspirations The literature also highlights the importance of family and community in relation to the aspirations of Indigenous young people (Craven et al. 2005; Parkes et al. 2015; Walker et al. 2008). In particular, in research that investigated Indigenous young people who moved around remote, regional, and urban localities, aspirations for education and employment were often secondary to the priority of family (Parkes et al. 2015). Indigenous young people have also been found to want to help their community (Parkes et al. 2015; Walker et al. 2008) and to make a contribution to society, in general, and community, in particular (Craven et al. 2005). For some Indigenous school students, aspirations for the future also relate to becoming a parent and starting a family (Mohajer et al. 2009; Walker et al. 2008). In the work of Craven et al. (2005), both Indigenous and non-Indigenous students were found to identify long-term relationships, family, and acquiring a house as important life goals.

\section{Enablers to pursuing aspirations and accessing higher education}

From the identified literature, 22 publications ascertained enablers to pursuing aspirations and accessing higher education for Indigenous students. These studies were conducted within higher education contexts $(n=14)$-particularly in relation to Indigenous students currently enrolled in, or who had graduated from, access courses, undergraduate and postgraduate university degrees-and/or in relation to Indigenous young people prior to pursuing their post-secondary pathway $(n=10)$. Two studies covered both contexts.

Several articles illustrated that the support and understanding of others, particularly within the family and community, can be crucial for Indigenous young people to feel that they can pursue their aspirations in general, and access higher education in particular (Craven et al. 2005; Lette et al. 2009; Nelson and Hay 2010; Rahman 2010; Walker et al. 2008). This was similar in studies focused on Indigenous students already enrolled in higher education (Cameron and Robinson 
2014; Kinnane et al. 2014; Santoro 2010). This research emphasises the importance of role models, particularly those with experience of university (Harwood et al. 2015; Kippen et al. 2006; Lette et al. 2009; Nelson and Hay 2010; Shah and Widin 2010; Walker et al. 2008). Rahman (2010) also found that being a role model for others provides impetus for some Indigenous school students to complete secondary school, a fundamental stepping-stone to higher education.

Exposure and accessibility to information and experiences were also identified in a number of articles as important facilitators of educational and occupational aspirations (Barney 2013; Cameron and Robinson 2014; Chirgwin 2014; Fleet et al. 2012; Hossain et al. 2008; Kinnane et al. 2014; Senior and Chenhall 2012; Shah and Widin 2010; Walker et al. 2008). Specifically, having direct involvement with the higher education environment prior to enrolment, such as through university-based programs that provide students with a connection to higher education, has been identified as an important enabler (Cameron and Robinson 2014; Harwood et al. 2015; Kinnane et al. 2014; O'Shea et al. 2013; Rahman 2010; Shah and Widin 2010; Turnbull 2014). Relatedly, for both Indigenous students in secondary school and those who have entered university, economic forms of support, such as scholarships and industry partnerships, have been identified as incentives, with knowledge of these schemes similarly found to be important (Hossain et al. 2008; Kinnane et al. 2014). Alternative entry pathways to university were also identified (Bandias et al. 2014; Chirgwin 2014; Fleet et al. 2012; Fredericks et al. 2015; Kinnane et al. 2014; Shah and Widin 2010) but, interestingly, only within studies that focused on Indigenous students already enrolled in university. A number of these studies suggest that students have utilised these routes to gain access to university, although no studies addressed school students' knowledge of these avenues.

In a number of studies, schooling was identified as a critical factor in relation to Indigenous school students, particularly relationships between teachers and students, access to resources, and cultural responsiveness within the school environment (Mander et al. 2015; Rahman 2010; Walker et al. 2008). Two relatively large quantitative analyses identified achievement and academic selfconcept as positively relating to educational aspirations for Indigenous students in secondary school (Craven et al. 2005; De Bortoli and Cresswell 2004). On an individual level, socioeconomic status has also been found to be related to the aspirations of Indigenous students during school (Craven et al. 2005), as well as students' own motivation and determination (Lette et al. 2009; Mander et al. 2015; Rahman 2010; Walker et al. 2008).

\section{Barriers to pursuing aspirations and accessing higher education}

From the identified literature, 21 publications discussed barriers to pursuing aspirations and accessing higher education for Indigenous students. As with the thematic analysis of enablers to accessing higher education, this research was conducted within higher education contexts $(n=10)$ and/or in relation to Indigenous young people prior to pursuing their post-secondary pathway $(n=12)$. One study covered both contexts. 
A central theme within many articles was a lack of career guidance and lack of knowledge about careers and further education. While enhancing infrastructure to support the attainment of further education and job seeking for Indigenous young people has been highlighted more generally (Mission Australia 2014), several studies also identified a perceived dearth of information about university and careers within communities and schools (Cameron and Robinson 2014; Hossain et al. 2008; Kippen et al. 2006; Oliver et al. 2013). Although some Indigenous school students have been found to be unsure of pathways to university specifically, and how to achieve their aspirations more broadly (Craven and Marsh 2004; Craven et al. 2005; Nelson and Hay 2010), some studies indicate that Indigenous young people can also be unaware of the options available to them post compulsory schooling (Kelly et al. 2009; Walker et al. 2008).

There are multiple reasons why Indigenous students might be unfamiliar with university specifically, including a lack of direct experience with the higher education environment or being the first in their family to attend an institution of higher education (Cameron and Robinson 2014; Kinnane et al. 2014; O'Shea et al. 2013). The articles highlight that this unfamiliarity can also stem from restricted life opportunities and local facilities, with geographic location being identified as a physical barrier to Indigenous young people from rural and remote communities accessing further opportunities (Mission Australia 2014; Senior and Chenhall 2012; Walker et al. 2008), and university in particular (Hossain et al. 2008; Kinnane et al. 2014; Kippen et al. 2006). Connected with this barrier are experiences of relocation and dislocation when Indigenous students need to move away from family and community to pursue many educational opportunities, identified by students both during their schooling (Craven et al. 2005; Walker et al. 2008) as well as during/ after enrolment in higher education (Fleet et al. 2007; Kippen et al. 2006). In other studies focusing on Indigenous students both prior to and those already at university, both financial pressures (Hossain et al. 2008; Kinnane et al. 2014; Kippen et al. 2006; Walker et al. 2008) and social- and health-related issues (Craven et al. 2005; Walker et al. 2008) presented barriers to students pursuing their aspirations.

While a lack of educational role models can present a critical barrier for some Indigenous students (Kippen et al. 2006; Walker et al. 2008), intergenerational educational experiences are pertinent in the literature for both Indigenous school students and those enrolled in university. These include limited access, historically, to education (Craven et al. 2005; Kippen et al. 2006); the views of university held by some Indigenous peoples and communities (Aseron et al. 2013a, b); and, the perception of Indigenous young people that racism is persistent in both education and employment (Craven et al. 2005; Hossain et al. 2008; Walker et al. 2008). Studies indicate that Indigenous students can favour TAFE as the more appropriate pathway for its practical nature and perceived work opportunities (Craven et al. 2005; Hossain et al. 2008; Kinnane et al. 2014; Kippen et al. 2006; Mission Australia 2014). Yet it has also be found that Indigenous students are directed towards TAFE by others within the school environment (Kinnane et al. 2014) or towards work by their parents (Barney 2013). Subsequently, a lack of support and encouragement to pursue any form of further education from those within the family and community has been identified as a potential barrier, recognised by both 
Indigenous school students (Craven and Marsh 2004; Craven et al. 2005; Hossain et al. 2008; Walker et al. 2008) and those in higher education (Cameron and Robinson 2014; Kippen et al. 2006).

In relation to schooling, research has also identified Indigenous students' disillusionment with education and a need for culturally appropriate teaching (Cameron and Robinson 2014; Kippen et al. 2006; Walker et al. 2008). Some Indigenous school students have identified inadequate facilities and resources in their local school (Mander et al. 2015), and certain courses and information not being presented to them (Nelson and Hay 2010). These studies also suggest a complex amalgam of factors that act as a barrier to completing school, as well as seeking access to further education, and university in particular. Such factors include low expectations communicated by teachers during schooling (Craven et al. 2005; Godfrey et al. 2001); a lack of confidence, anxiety, and low academic selfconcept among students also during school (Craven et al. 2005; Hossain et al. 2008; Walker et al. 2008); and, not meeting the minimum level of academic achievement required for entry to university (Craven and Marsh 2004; Craven et al. 2005; Hossain et al. 2008; Kinnane et al. 2014; Walker et al. 2008). In particular, in an analysis of longitudinal data over eight years, commencing with students at age 15 and following them as they pursued their post-school destinations, inequalities in university entry rates for Indigenous students were found to be affected by levels of achievement during school (Parker et al. 2015).

\section{Enablers to participation, retention, and completion in higher education}

From the identified literature, 30 publications were associated with enablers to participation, retention, and completion in higher education. Of these articles, all had an explicit focus on higher education. Participants were current or former university students, with some studies also sampling staff members and other stakeholders.

The support provided by Indigenous Centres within higher education institutions was a commonly identified enabler. These centres not only provide formal academic support but also tangible resources for students and a venue for social, cultural, and community activities (Cameron and Robinson 2014; Fleet et al. 2007; Howlett et al. 2008; Kinnane et al. 2014; Kippen et al. 2006; Morgan 2001; Oliver et al. 2013, 2015; Page and Asmar 2008; Pechenkina et al. 2011; Sonn et al. 2000; Usher et al. 2005; West et al. 2014). In the wider university environment, the support provided by both Indigenous and non-Indigenous academics was highlighted (Cameron and Robinson 2014; Fredericks et al. 2015; Oliver et al. 2013, 2015; Page and Asmar 2008; Rigby et al. 2010; Sharrock and Lockyer 2008; Usher et al. 2005; West et al. 2014). Furthermore, inclusive environments that incorporate Indigenous content in curricula and involve members of the local Indigenous community were found to be important enablers for ongoing participation and retention (DiGregorio et al. 2000; Howlett et al. 2008; Turnbull 2014; Usher et al. 2005).

Relatedly, positive experiences in the classroom (Bandias et al. 2014; Hossain et al. 2008; Shah and Widin 2010) and experiences at university that increase selfesteem and confidence (Bandias et al. 2014; Plater 2013) have been identified as 
vital for some students. Access to appropriate information, infrastructure, and resources within the university has also been highlighted (Barney 2013; Hossain et al. 2008; Oliver et al. 2013, 2015; Usher et al. 2005), facilitated through support services and programs (Barney 2013; Fleet et al. 2007; Hossain et al. 2008; Morgan 2001; Oliver et al. 2013; Shah and Widin 2010; Usher et al. 2005). A number of these studies also show that formal and informal mentoring provides a mechanism for engagement on campus as well as a source of information about university systems and procedures (Barney 2013; Cameron and Robinson 2014; Fleet et al. 2012; Kinnane et al. 2014; Mills et al. 2014; Oliver et al. 2013; Sharrock and Lockyer 2008; Usher et al. 2005). Support from peers, opportunities for networking, and other social aspects of university life provide important connections (Barney 2013; Fleet et al. 2007; Morgan 2001; Oliver et al. 2013, 2015; Rigby et al. 2010; Usher et al. 2005; West et al. 2014). These connections assist students to feel a sense of belonging within the higher education environment (Hossain et al. 2008; Rigby et al. 2010; Usher et al. 2005).

Within the university, financial support, often in the form of scholarships, has been perceived as aiding in reducing economic hardship faced by students and their families (Cameron and Robinson 2014; Fleet et al. 2007; Fredericks et al. 2015; Hossain et al. 2008; Usher et al. 2005). Moreover, the flexibility within degrees, in the form of block- or mixed-mode attendance, or distance/online education, have been identified as positive structures enhancing support for students and taking into account personal and family commitments (Fleet et al. 2012; Gibb 2006; Oliver et al. 2013; Sharrock and Lockyer 2008; Turnbull 2014; Usher et al. 2005). Degree programs that offer placements and internships are have also been linked with positive outcomes of the university experience (Bandias et al. 2014; Hossain et al. 2008; Kinnane et al. 2014).

Outside of university, family support and encouragement are important enablers for participation and retention (Oliver et al. 2015); however, support and understanding from peers and the community are just as vital in many instances (Cameron and Robinson 2014; Fleet et al. 2007, 2012; Fredericks et al. 2015; Kippen et al. 2006; Morgan 2001; Oliver et al. 2013; Santoro 2010; Usher et al. 2005; West et al. 2014). A student's personal circumstances and motivation can also be imperative (Boulton-Lewis et al. 2004; Morgan 2001; Oliver et al. 2013; Toombs and Gorman 2010; Usher et al. 2005; West et al. 2014), as well as personal qualities such as motivation and discipline (Oliver et al. 2015). Becoming a role model and mentoring other students has also been seen to inculcate a sense of the enormity of being a university student, as well as instil stability and resilience (Cameron and Robinson 2014; DiGregorio et al. 2000; Howlett et al. 2008; Kinnane et al. 2014; O'Shea et al. 2013).

\section{Barriers to participation, retention, and completion in higher education}

From the identified literature, 27 publications were associated with barriers to participation, retention, and completion in higher education. Of these articles, only one did not have an explicit focus on higher education; this article encompassed 
both university and TAFE pathways. Participants were current or former university students, with some studies also sampling staff members and other stakeholders.

Institutional barriers were a major focus of many articles, and included a perceived lack of support and obstacles in accessing the anticipated or required information; these challenges can culminate in students feeling unequipped to navigate the university system (Aseron et al. 2013b; Asmar et al. 2015; Cameron and Robinson 2014; DiGregorio et al. 2000; Ellender et al. 2008; Fleet et al. 2007; Gibb 2006; Howlett et al. 2008; Kinnane et al. 2014; Kippen et al. 2006; Oliver et al. 2013, 2015; Plater 2013; Rigby et al. 2010; Trudgett 2009; Usher et al. 2005). Closely connected is the inclusion/exclusion of Indigenous content; in some instances there was a lack of identifiable content in the curriculum; in others, the content was perceived as culturally inappropriate or incorrect (Aseron et al. 2013b; Cameron and Robinson 2014; Gibb 2006; Oliver et al. 2013; Rigby et al. 2010; Sonn et al. 2000; Usher et al. 2005). There can also be a perception that Indigenous knowledges are not valued within the Western academy (Harrison 2004; Rochecouste et al. 2014) or that they conflict with Western perspectives on learning and knowledge (Aseron et al. 2013b; Barney 2013; Kinnane et al. 2014; Oliver et al. 2013; Rochecouste et al. 2014; Sonn et al. 2000; Usher et al. 2005).

Within the university environment, perceptions of cultural insensitivity, a lack of cultural awareness and respect, and a dearth of engagement with the local Indigenous community are all reported as significant barriers to ongoing retention (Aseron et al. 2013b; Bandias et al. 2014; Cameron and Robinson 2014; Hossain et al. 2008; Kinnane et al. 2014; Kippen et al. 2006; Oliver et al. 2013; Rigby et al. 2010; Sonn et al. 2000; Usher et al. 2005). Experiences of racism within the university, stereotyping, and exclusion (Cameron and Robinson 2014; Gibb 2006; Oliver et al. 2013; Rochecouste et al. 2014; Sonn et al. 2000; Trudgett 2009; Usher et al. 2005), and an absence of Indigenous staff and students (Barney 2013; Cameron and Robinson 2014; Kippen et al. 2006; Rochecouste et al. 2014; Trudgett 2009), are all closely related to feelings of cultural and social isolation experienced by some Indigenous students (Barney 2013; Ellender et al. 2008; Kinnane et al. 2014; Rochecouste et al. 2014). Other institutional barriers on campus include accommodation and childcare-related issues (Bandias et al. 2014; DiGregorio et al. 2000; Kinnane et al. 2014).

While geographic location and travel are key concerns (Fleet et al. 2007; Kinnane et al. 2014; Rigby et al. 2010), experiences of relocation and dislocation from one's family and community can be particularly challenging (DiGregorio et al. 2000; Ellender et al. 2008; Fleet et al. 2007; Fredericks et al. 2015; Kinnane et al. 2014; Kippen et al. 2006; Santoro 2010; Sonn et al. 2000; Usher et al. 2005), leading some Indigenous students to experience a sense of 'culture shock' (Cameron and Robinson 2014; Sonn et al. 2000; Usher et al. 2005). Balancing other commitments within the family and/or community can place a strain on studies (Aseron et al. 2013b; Asmar et al. 2015; Chirgwin 2014; Ellender et al. 2008; Fleet et al. 2007; Fredericks et al. 2015; Hillman 2005; Kinnane et al. 2014; Kippen et al. 2006; Oliver et al. 2013, 2015; Rigby et al. 2010; Sonn et al. 2000; Toombs and Gorman 2010; Usher et al. 2005), especially when university is thought of in a negative light by others (Barney 2013; Cameron and Robinson 2014; Morgan 2001). 
Intergenerational experiences, as well as one's own past experiences with educational institutions (Harrison 2004; Oliver et al. 2013; Toombs and Gorman 2010), physical and mental health issues (Chirgwin 2014; Rigby et al. 2010; Toombs and Gorman 2010), and financial concerns (Aseron et al. 2013b; Asmar et al. 2015; Bandias et al. 2014; Ellender et al. 2008; Fleet et al. 2007; Hillman 2005; Kinnane et al. 2014; Morgan 2001; Oliver et al. 2013; Rigby et al. 2010; Toombs and Gorman 2010; Trudgett 2009; Usher et al. 2005) have also been found to impact on retention. For some students, it might 'just not be the right time' to study at university (Fredericks et al. 2015).

Low self-esteem, lack of confidence, and self-doubt have also been identified as underlying concerns (Gibb 2006; Usher et al. 2005). These are closely related to academic issues such as developing study skills, time management, and one's perceived ability and educational preparedness (Asmar et al. 2015; Ellender et al. 2008; Fleet et al. 2007; Fredericks et al. 2015; Gibb 2006; Rigby et al. 2010; Usher et al. 2005), as well as access to appropriate resources and technology (DiGregorio et al. 2000; Fleet et al. 2007; Kinnane et al. 2014; Oliver et al. 2013; Usher et al. 2005). Personal experiences can also be affected by feeling the weight of responsibility regarding Indigenous culture, and the perceived pressure to succeed by others within the family and community (Cameron and Robinson 2014; Gibb 2006; Kinnane et al. 2014; Oliver et al. 2013; Sonn et al. 2000).

\section{Discussion}

As a result of this scoping review, 57 articles published between 2000 and 2016 were identified that presented data related to the participation of Indigenous students in the Australian higher education sector. The review demonstrated increasing scholarly attention to this topic since the Bradley Review and further intensification since the Behrendt Report. This rise in the number of publications signals increased efforts to generate a solid empirical base for enhancing equity for Indigenous Australians in higher education. In the following section, we discuss four key insights that arose from our analysis, each with implications for future research.

\section{Learning from Indigenous school students}

A clear finding of this review is that the majority of studies have been conducted with Indigenous students who have already made it to university. Around twothirds of the publications analysed for this review involved Indigenous students after the point of enrolment. Equity initiatives in higher education typically target five periods in the student 'life cycle': prior to accessing higher education; during selection and/or admission; during transition to university; during studies; and, post-completion (Naylor et al. 2013). A recent national review found that university equity initiatives are frequently directed at secondary school students, often focused on raising or expanding aspirations (Bennett et al. 2015). 
Arguably, much of this activity is based more on perception than on an understanding of students' actual aspirations (Corbett and Forsey 2017; Gore et al. 2015).

In order to better understand how initiatives can be designed and implemented to effectively support Indigenous students, our review highlights the need for a stronger evidence base at the initial stage of this cycle, focusing not only on secondary students but also on primary students. Both Australian (Gore et al. 2015) and international research (Archer et al. 2013; Whitty et al. 2015) has shown that primary school-aged students are already beginning to situate themselves in relation to educational and occupational futures. Growing recognition that aspirations begin to take shape well before the point when students seek access to higher education signals the urgency of further empirical research with school students.

Furthermore, few studies focused solely on the higher education aspirations of Indigenous school students, with most studies including higher education as one of many post-secondary pathways. While this research provides an important foundation to understanding the aspirations of Indigenous students, targeted research on school student aspirations for higher education is essential in light of continuing disparities in access and participation rates. An increased focus on Indigenous school students may be critical in understanding how higher education is perceived and how individuals view the desirability and possibility of accessing this pathway (Gore et al. in press). Research undertaken at this early stage in the student life cycle also has the potential to address the early identification of barriers and to capitalise on enablers to participation in higher education, thus providing crucial evidence to inform and strengthen equity policy and programs.

\section{Going beyond barriers and enablers}

Another insight emerging from the analysis of the literature was that several barriers and enablers were consistently identified across the areas of aspirations, access, participation, retention, and completion. For example, relocation and dislocation from family and community were consistently identified as barriers to participation in higher education in studies addressing different points of the student life cycle. These aspects of Indigenous students' experience increase the complexity of gaining access to university in the first place and may persist for students throughout their studies. A number of enabling factors were also identified as significant for Indigenous students prior to and during participation in higher education. The support and understanding of family and community, for example, was found to be crucial to students pursuing their aspirations, as well as during participation in higher education.

While many studies highlighted barriers to Indigenous student participation in higher education, studies that identified enablers provide an important foundation for further empirical research as well as targeted equity initiatives. The similitude of barriers and enablers across stages also suggests the need for further empirical research to move beyond these constructs towards more nuanced understandings of the 'emotional aspects and material realities' (Corbett and Forsey 2017) of 
Indigenous students' lives, recognising the heterogeneity within and between Indigenous communities.

\section{Recognising difference within Indigenous community}

A further insight from this scoping review is that factors identified as impacting on Indigenous students' relationship to higher education manifested as barriers for some and enablers for others. For example, the level of support or encouragement from family and community was identified as both a barrier and enabler to aspiration, access, participation, retention, and completion. The range of effects associated with any single factor underscores the importance of recognising the particular circumstances of Indigenous students, rather than 'essentialising' Indigenous students as a single equity category (see Day et al. 2015; Walter 2010). While understanding wider societal influences on Indigenous students as a group is an important component of the equity agenda, further research that seeks to more fully understand differences within Indigenous communities and among Indigenous students will enable a more nuanced approach to the provision and implementation of targeted support.

\section{Developing new approaches to understanding Indigenous participation in higher education}

Despite the growth in published research since the Bradley Review, the same barriers and enablers surfaced in studies spanning the entire period of our scoping review, 2000-2016. Although there have been important gains in access to higher education for Indigenous students (Behrendt et al. 2012) during this period, the apparent intransigence of these factors signals the need for new approaches to policy, practice, and research in relation to the participation of Indigenous students in higher education. If further advances are to be made in addressing the underrepresentation of Indigenous students in higher education, there is still much to do to ensure that equity initiatives are effective, targeting the real needs of students, their families, and communities.

The body of literature identified within this scoping review provides an important basis for ongoing research. Studies ranged from small scale qualitative accounts of the experience of Indigenous students through to quantitative analyses of large data sets. Collectively the studies reinforce the importance of overcoming barriers and strengthening enablers to support Indigenous students in higher education. However, given ongoing evidence showing the disparity between Indigenous and non-Indigenous students, our scoping review suggests that new forms of empirical work might be needed. Important insights for further empirical study may be found in Indigenous scholarship including work using Indigenous methodologies that do not yet appear to have translated into empirical studies (see, for example, BodkinAndrews and Carlson 2014; Day et al. 2015; Devlin 2009; O’Bryan 2015; Walter 2015). Indeed, a greater embrace of Indigenous methodologies and insights from Indigenous scholarship in designing rigorous empirical studies, in collaboration with Indigenous scholars, may be critical to understanding Indigenous students' 
experience of higher education and generating a stronger evidence base for targeted and meaningful support.

\section{Conclusion}

This scoping review contributes a valuable synthesis of empirical research on the participation of Indigenous students in the Australian higher education sector. Developing a strong evidence base to underpin equity initiatives is critical to supporting students from underrepresented groups as they attempt to access and participate in university (Bennett et al. 2015; Naylor et al. 2013). For Indigenous students in particular, with enduring disparities in access, participation, retention, and completion (Behrendt et al. 2012; Bennett et al. 2015), it is critical to understand what is needed to achieve and sustain substantially better outcomes. This review has not only highlighted these disparities but their persistence over the last 16 years. In light of recent reports calling for improved outcomes for Indigenous Australians (Behrendt et al. 2012; Commonwealth of Australia 2017), this scoping review provides timely impetus for exploring new approaches to research on Indigenous students in higher education.

Higher education has a crucial role to play in improving employment, economic, and health outcomes for Indigenous Australians (Commonwealth of Australia 2017). We argue that future research should take account of school student aspirations for higher education, including primary school students; the similitude of barriers and enablers across the student life cycle; differences within Indigenous community and among Indigenous students; and, the insights emerging from Indigenous methodologies and scholarship. We trust this review provides a valuable resource for further research in this area that expands and builds upon the existing evidence base.

Acknowledgements This analysis was undertaken as part of a study funded by the Australian Government Department of Education and Training under the Higher Education Participation Program's National Priorities Pool scheme, and supported by the Teachers and Teaching Research Centre and Centre of Excellence for Equity in Higher Education at the University of Newcastle, Australia. The authors also wish to acknowledge the support of Le Hoang Le in the preparation of this manuscript.

Open Access This article is distributed under the terms of the Creative Commons Attribution 4.0 International License (http://creativecommons.org/licenses/by/4.0/), which permits unrestricted use, distribution, and reproduction in any medium, provided you give appropriate credit to the original author(s) and the source, provide a link to the Creative Commons license, and indicate if changes were made.

\section{Appendix}

See Table 1. 


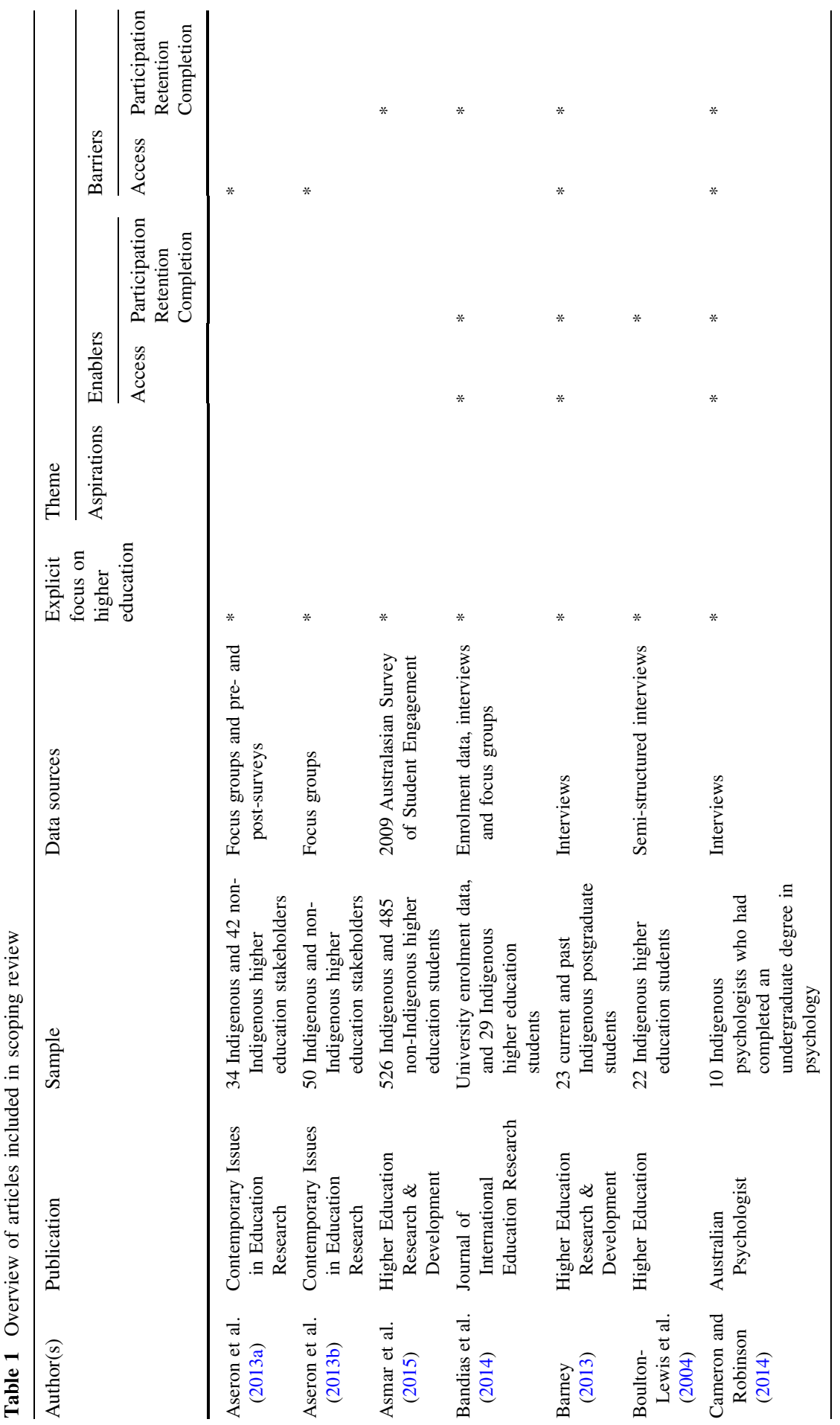




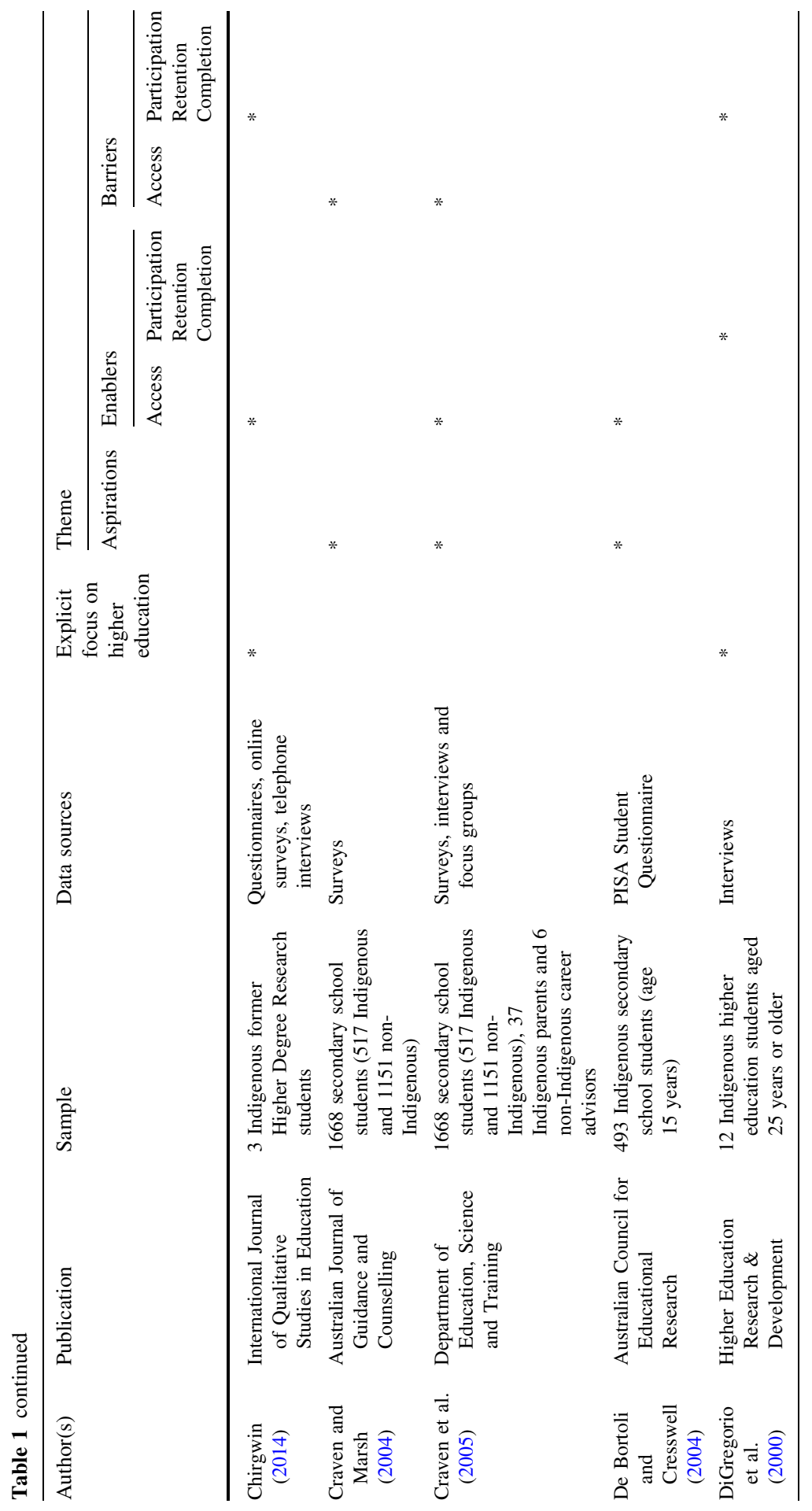




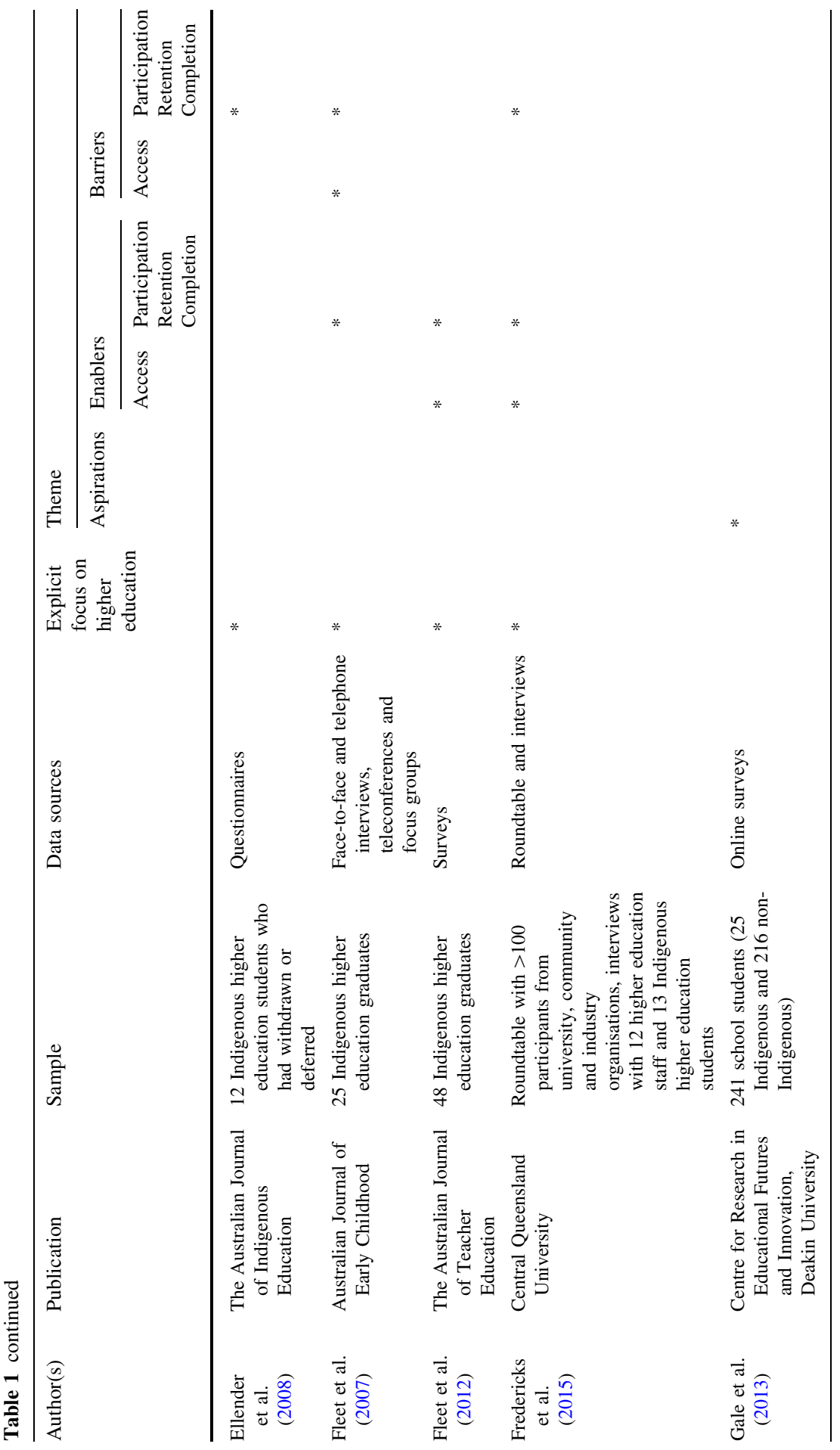




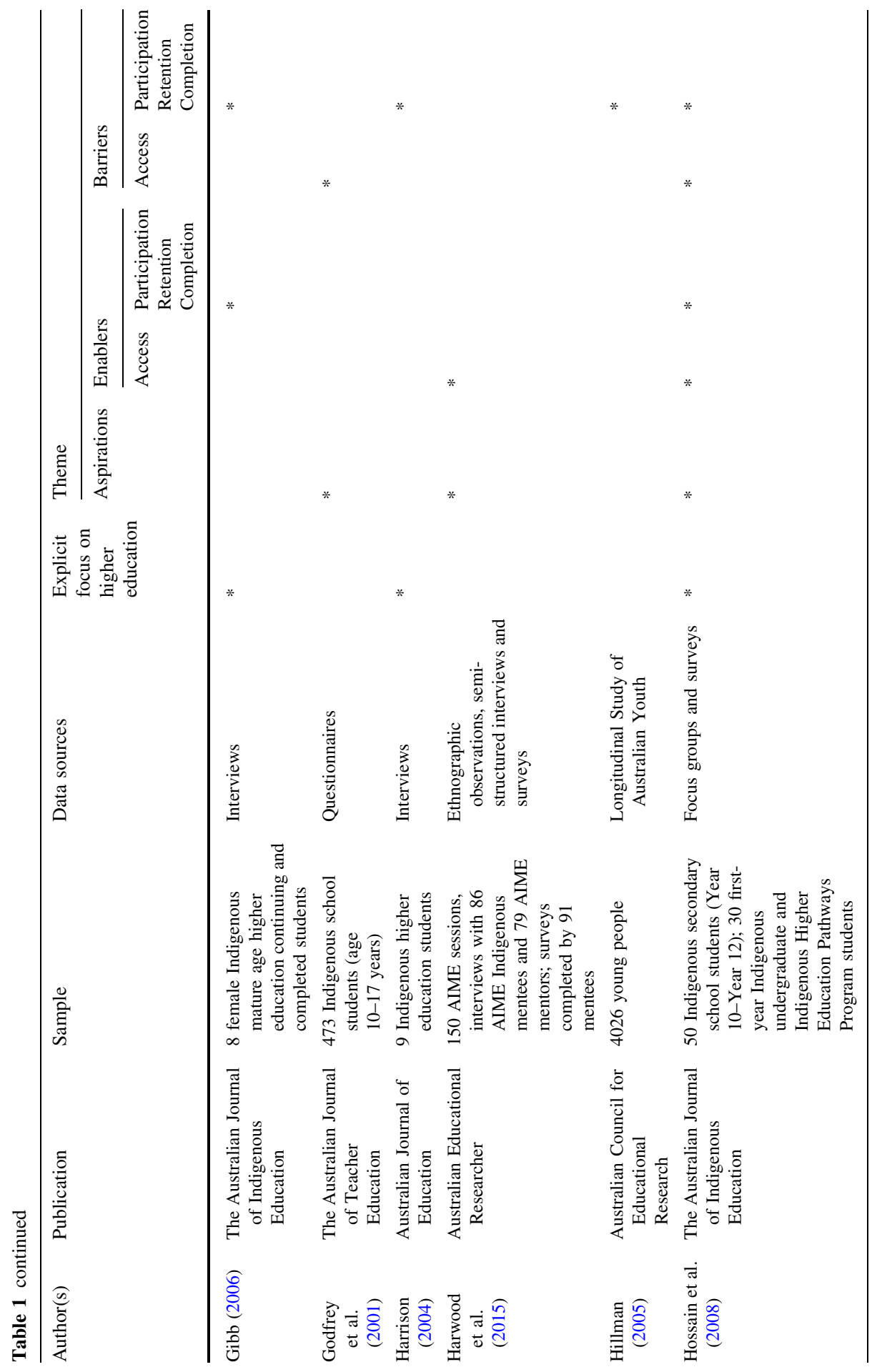




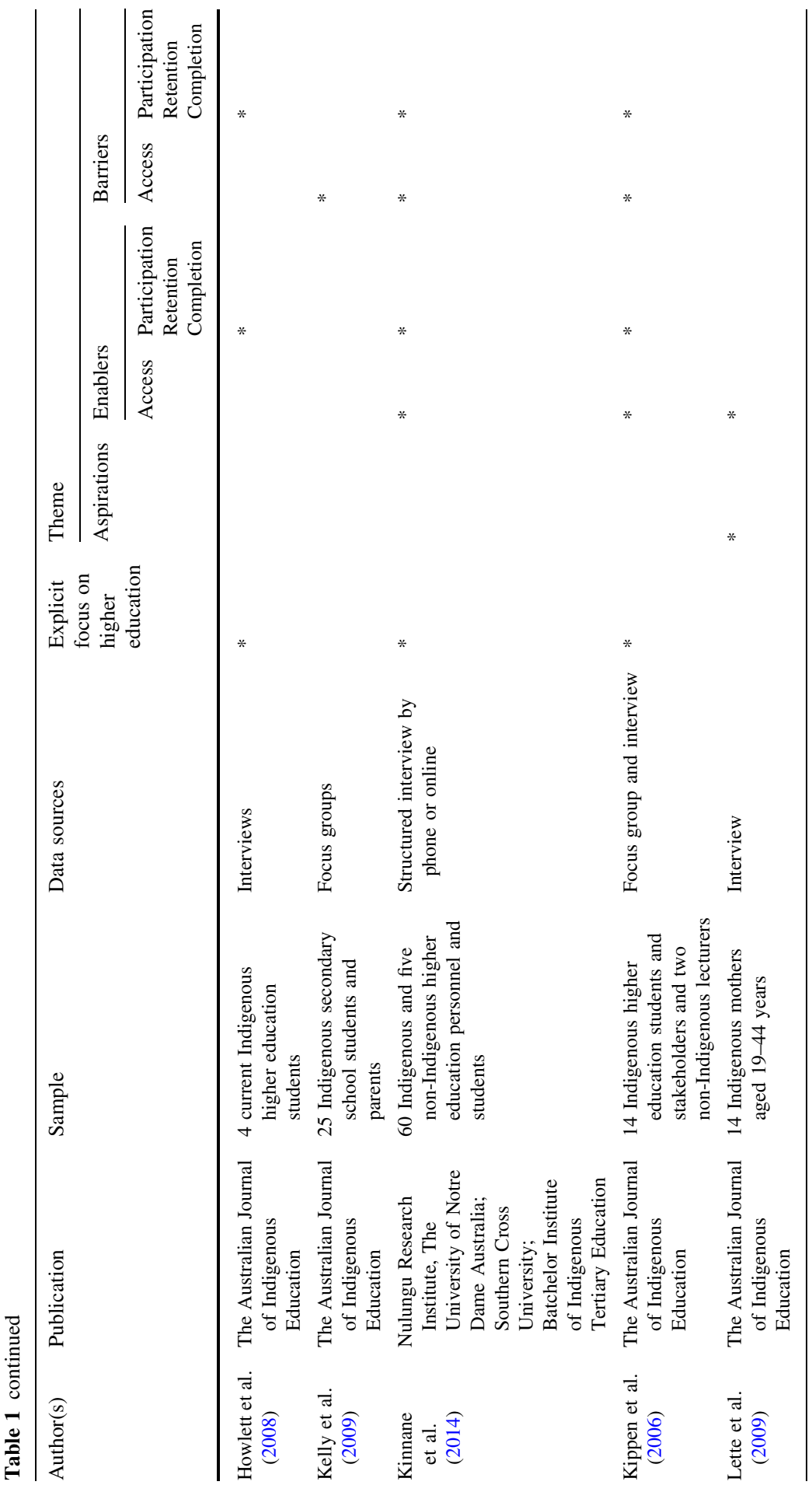




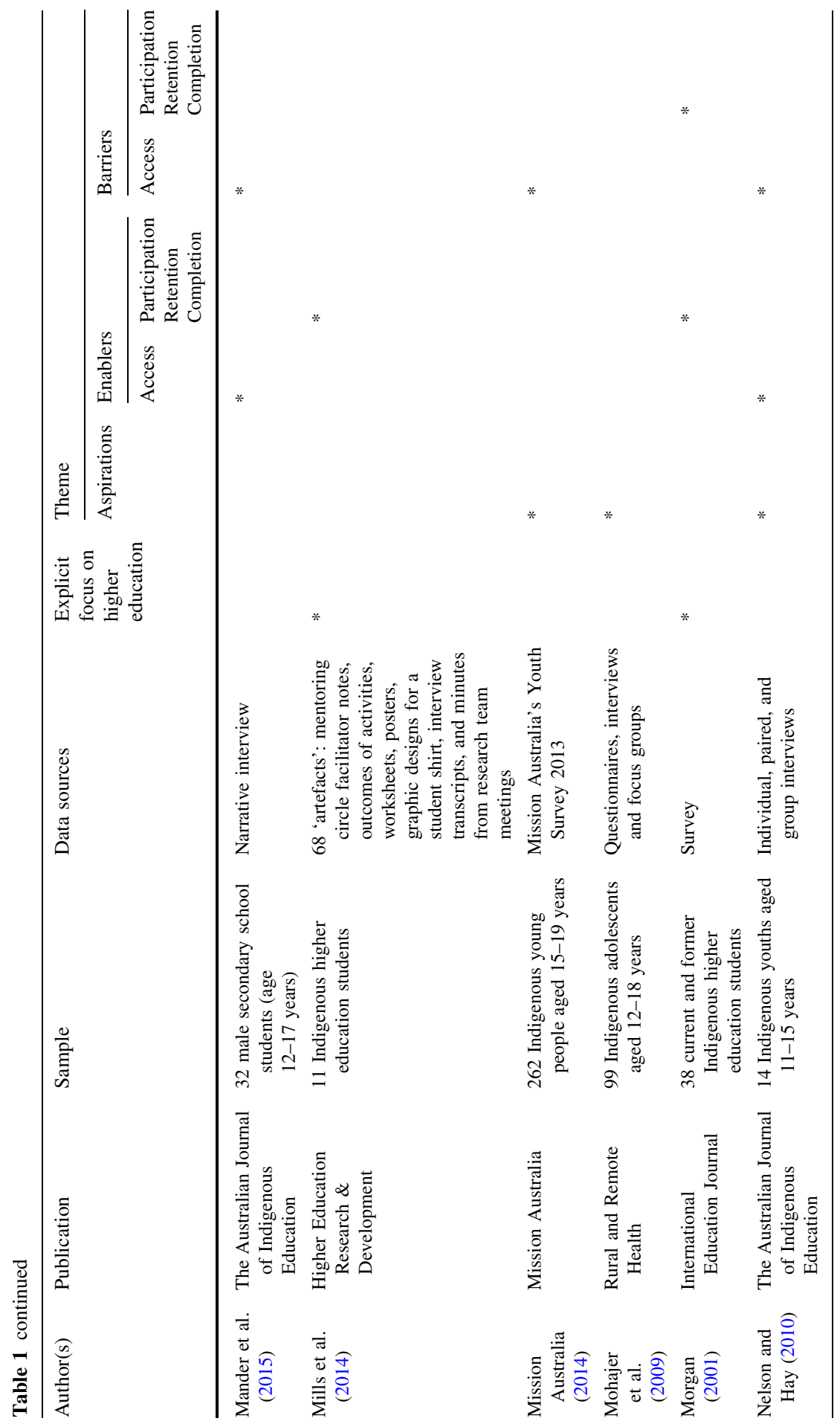




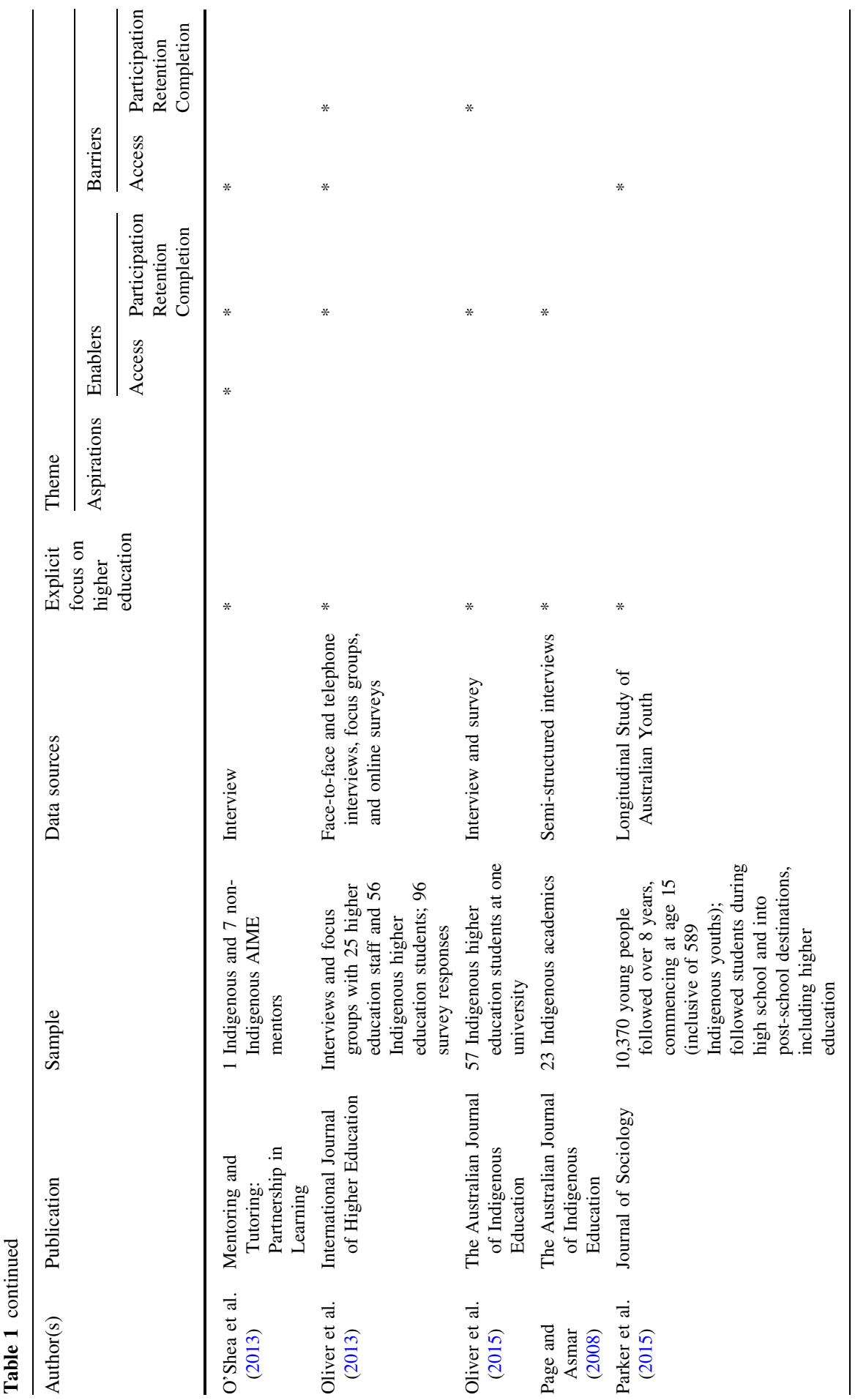




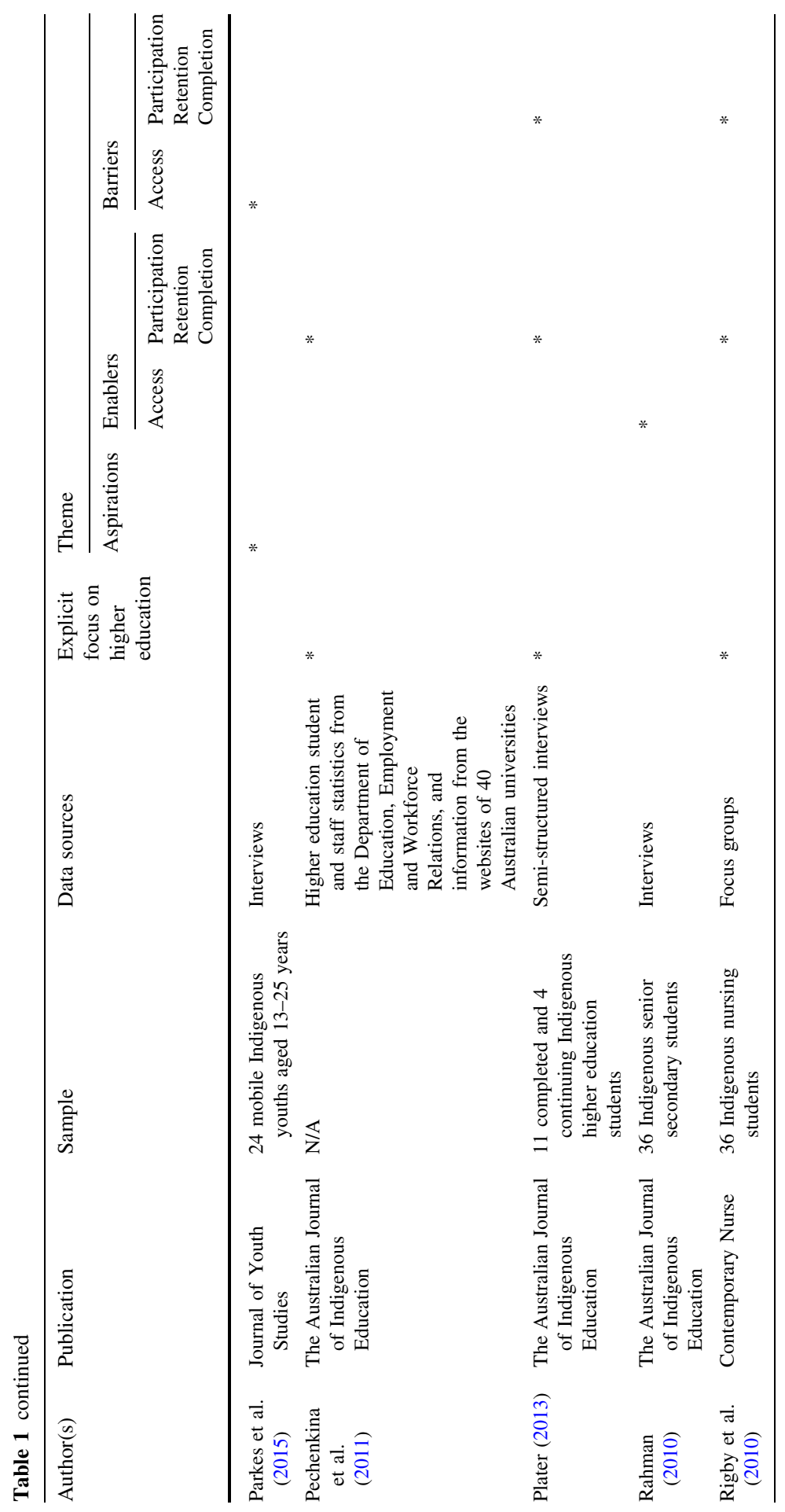




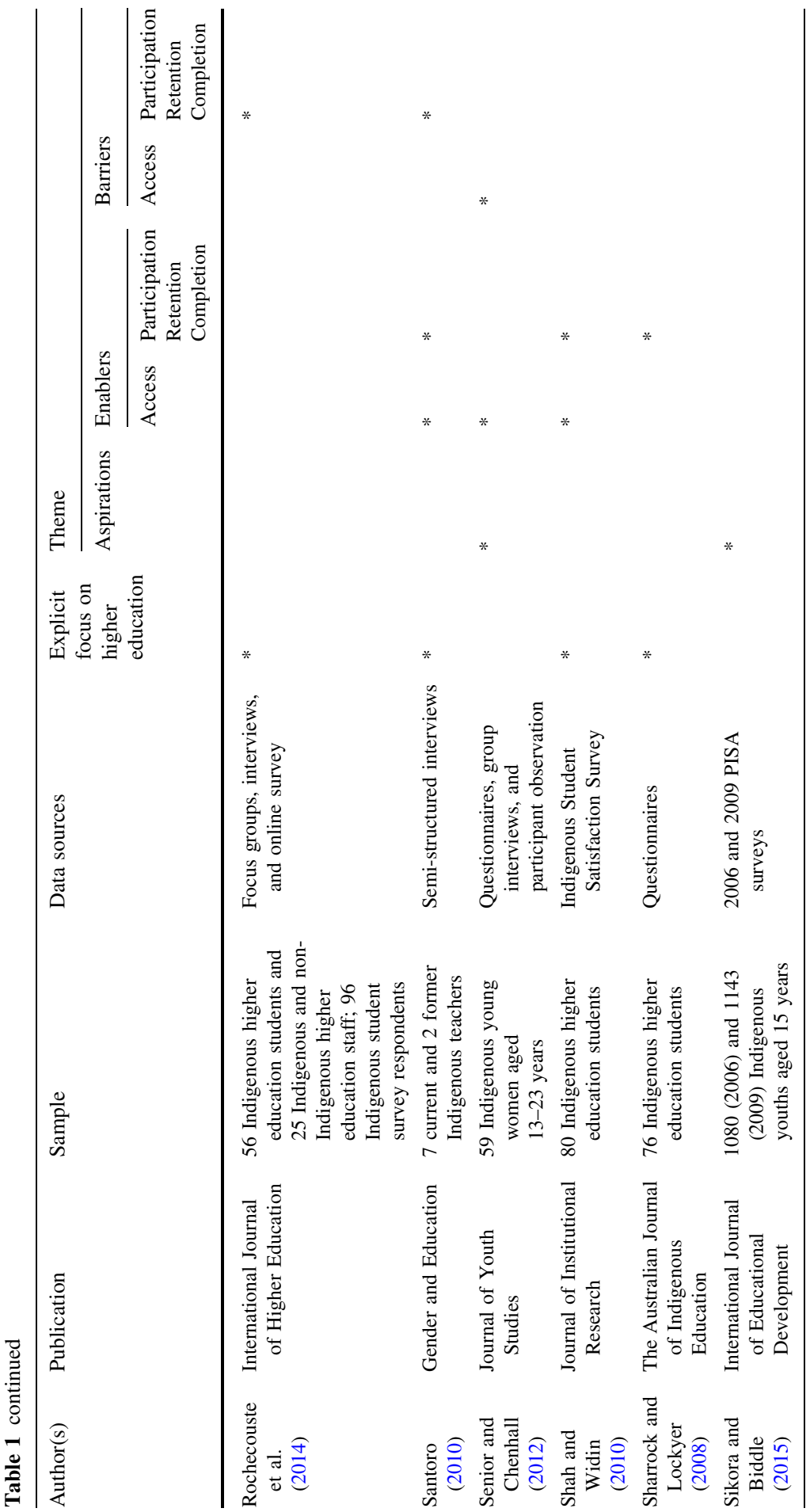




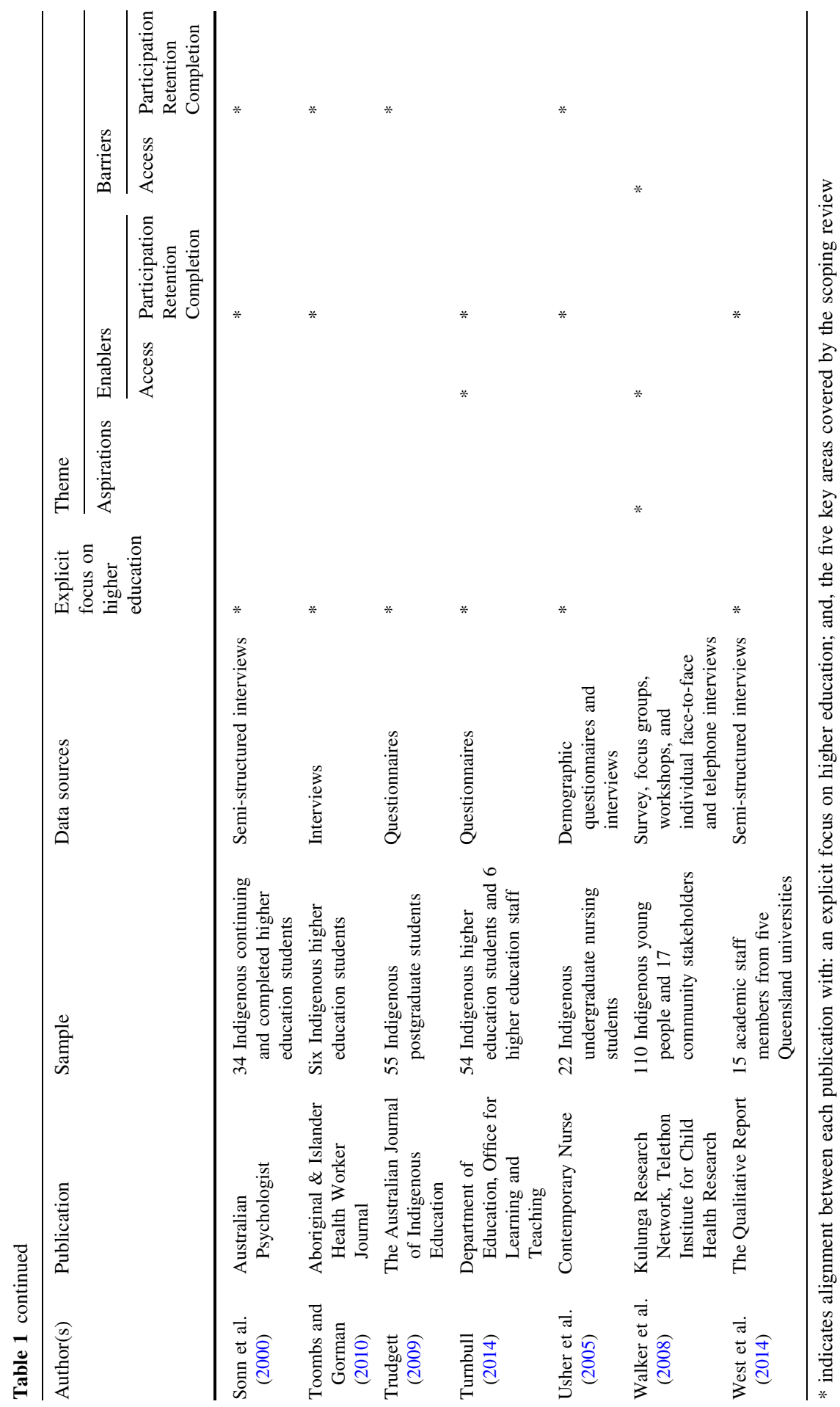




\section{References}

Anderson, S., Allen, P., Peckham, S., \& Goodwin, N. (2008). Asking the right questions: Scoping studies in the commissioning of research on the organisation and delivery of health services. Health Research Policy and Systems (Online). doi:10.1186/1478-4505-6-7.

Archer, L., DeWitt, J., \& Wong, B. (2013). Spheres of influence: What shapes young people's aspirations at age 12/13 and what are the implications for education policy? Journal of Education Policy, 29, 58-85. doi:10.1080/02680939.2013.790079.

Arksey, H., \& O'Malley, L. (2005). Scoping studies: Towards a methodological framework. International Journal of Social Research Methodology, 8, 19-32. doi:10.1080/1364557032000119616.

Aseron, J., Greymorning, S. N., Miller, A., \& Wilde, S. J. (2013a). Cultural safety circles and Indigenous people's perspectives: Inclusive practices for participation in higher education. Contemporary Issues in Education Research, 6, 409-416. Retrieved March 3, 2016 from http://www.cluteinstitute.com/ ojs/index.php/CIER/article/view/8109.

Aseron, J., Wilde, S. J., Miller, A., \& Kelly, S. J. (2013b). Indigenous student participation in higher education: Emergent themes and linkages. Contemporary Issues in Education Research, 6, 417-424. Retrieved March 16, 2016 from http://www.cluteinstitute.com/ojs/index.php/CIER/issue/view/868.

Asmar, C., Page, S., \& Radloff, A. (2015). Exploring anomalies in Indigenous student engagement: Findings from a national Australian survey of undergraduates. Higher Education Research \& Development, 34, 15-29. doi:10.1080/07294360.2014.934334.

Bandias, S., Fuller, D., \& Larkin, S. (2014). Indigenous students in the tertiary education sector. Journal of International Education Research, 10, 179-200. Retrieved February 22, 2016 from http:// cluteinstitute.com/ojs/index.php/JIER/article/view/8738.

Barney, K. (2013). 'Taking your mob with you': Giving voice to the experiences of Indigenous Australian postgraduate students. Higher Education Research \& Development, 32, 515-528. doi:10.1080/ 07294360.2012 .696186$.

Behrendt, L., Larkin, S., Griew, R., \& Kelly, P. (2012). Review of higher education access and outcomes for Aboriginal and Torres Strait Islander people: Final report. Canberra: Department of Education and Training. Retrieved February 1, 2016 from https://docs.education.gov.au/documents/reviewhigher-education-access-and-outcomes-aboriginal-and-torres-strait-islander-people-0.

Bennett, A., Naylor, R., Mellor, K., Brett, M., Gore, J., Harvey, A., ..., Whitty, G. (2015). The critical interventions framework part 2: Equity initiatives in Australian higher education: A review of evidence of impact. Retrieved September 30, 2016 from http://www.newcastle.edu.au/_data/assets/ pdf_file/0016/261124/REPORT-FINAL.pdf.

Bodkin-Andrews, G., \& Carlson, B. (2014). The legacy of racism and Australian Indigenous identity within education. Race, Ethnicity and Education, 19, 784-807. doi:10.1080/13613324.2014.969224.

Booth, A., Papaioannou, D., \& Sutton, A. (2012). Systematic approaches to a successful literature review. London: SAGE.

Boulton-Lewis, G. M., Marton, F., Lewis, D. C., \& Wilss, L. A. (2004). A longitudinal study of learning for a group of Indigenous Australian university students: Dissonant conceptions and strategies. Higher Education, 47, 91-112. doi:10.1023/b:high.0000009807.00392.33.

Bradley, D., Noonan, P., Nugent, H., \& Scales, B. (2008). Review of Australian higher education: Final report. Canberra: Department of Education, Employment and Workplace Relations. http://hdl. voced.edu.au/10707/44384. Retrieved 3 March 2016.

Cameron, S., \& Robinson, K. (2014). The experiences of Indigenous Australian psychologists at university. Australian Psychologist, 49, 54-62. doi:10.1111/ap.12036.

Chirgwin, S. (2014). Burdens too difficult to carry? A case study of three academically able Indigenous Australian masters students who had to withdraw. International Journal of Qualitative Studies in Education, 28, 594-609. doi:10.1080/09518398.2014.916014.

Commonwealth of Australia. (2012). Tertiary education quality and standards agency: About TEQSA. Retrieved April 9, 2017 from http://www.teqsa.gov.au/about.

Commonwealth of Australia. (2017). Closing the gap: Prime Minister's report 2017. Canberra: Department of the Prime Minsiter and Cabinet. Retrieved 14 March, 2017 from http://closingthegap. pmc.gov.au/sites/default/files/ctg-report-2017.pdf.

Corbett, M., \& Forsey, M. (2017). Rural youth out-migration and education: Challenges to aspirations discourse in mobile modernity. Discourse: Studies in the Cultural Politics of Education. doi:10. 1080/01596306.2017.1308456. 
Craven, R. G., \& Marsh, H. W. (2004). The challenge for counsellors: Understanding and addressing Indigenous secondary students' aspirations, self-concepts and barriers to achieving their aspirations. Australian Journal of Guidance and Counselling, 14, 16-33. doi:10.1017/s1037291100002648.

Craven, R. G., Tucker, A., Munns, G., Hinkley, J., Marsh, H., \& Simpson, K. (2005). Indigenous students' aspirations: Dreams, perceptions and realities. Canberra: Department of Education, Science and Training. Retrieved February 1, 2016 from http://www.voced.edu.au/content/ngv\%3A4477.

Day, A., Nakata, V., Nakata, M., \& Martin, G. (2015). Indigenous students' persistence in higher education in Australia: Contextualising models of change from psychology to understand and aid students' practices at a cultural interface. Higher Education Research \& Development, 34, 501-512. doi:10.1080/07294360.2014.973379.

De Bortoli, L., \& Cresswell, J. (2004). Australia's Indigenous Students in PISA 2000: Results from an international study. Retrieved February 4, 2016 from https://www.acer.edu.au/files/PISA_ RM59IndigScreen.pdf.

Devlin, M. (2009). Indigenous higher education student equity: Focusing on what works. The Australian Journal of Indigenous Education, 38(1), 1-8. doi:10.1375/s1326011100000533.

DiGregorio, K. D., Farrington, S., \& Page, S. (2000). Listening to our students: Understanding the factors that affect Aboriginal and Torres Strait Islander students' academic success. Higher Education Research \& Development, 19, 297-309. doi:10.1080/758484344.

Ellender, I., Drysdale, M., Chesters, J., Faulkner, S., Kelly, H., \& Turnbull, L. (2008). When a dream becomes a nightmare: Why do Indigenous Australian medical students withdraw from their courses? The Australian Journal of Indigenous Education, 37, 40-47. doi:10.1375/s1326011100000089.

Fleet, A., Kitson, R., Cassady, B., \& Hughes, R. (2007). University-qualified Indigenous early childhood teachers: Voices of resilience. Australian Journal of Early Childhood, 32, 17-25.

Fleet, A., Wechmann, K., \& Whitworth, R. (2012). Professional pathways of Aboriginal early childhood teachers: Intersections of community, Indigeneity, and complexity. The Australian Journal of Teacher Education, 37, 128-143. doi:10.14221/ajte.2012v37n9.7.

Fredericks, B., Kinnear, S., Daniels, C., Croft Warcon, P., \& Mann, J. (2015). Path+ways: Towards best practice in Indigenous access education. Retrieved April 19, 2016 from https://www.ncsehe.edu.au/ publications/pathways-towards-best-practice-bridging-indigenous-participation-regional-dualsector-universities/.

Gale, T., \& Parker, S. (2013). Widening participation in Australian higher education: Report submitted to the Higher Education Funding Council of England (HEFCE) and the Office of Fair Access (OFFA). Bristol, UK: HEFCE. Retrieved October 20, 2015 from http://www.ncsehe.edu.au/publications/ widening-participation-australian-higher-education/.

Gale, T., Parker, S., Rodd, P., Stratton, G., \& Sealey, T. (2013). Student aspirations for higher education in Central Queensland: A survey of school students' navigational capacities. Retrieved October 20, 2015 from https://www.deakin.edu.au/_data/assets/pdf_file/0016/365200/student-aspirations-qld. pdf.

Gibb, H. (2006). Distance education and the issue of equity online: Exploring the perspectives of rural Aboriginal students. The Australian Journal of Indigenous Education, 35, 21-29. doi:10.1017/ s1326011100004130.

Godfrey, J., Partington, G., Harslett, M., \& Richer, K. (2001). Attitudes of aboriginal students to schooling. The Australian Journal of Teacher Education, 26(1), 1-7. doi:10.14221/ajte.2001v26n1. 5.

Gore, J., Holmes, K., Smith, M., Southgate, E., \& Albright, J. (2015). Socioeconomic status and the career aspirations of Australian school students: Testing enduring assumptions. Australian Educational Researcher, 42, 155-177. doi:10.1007/s13384-015-0172-5.

Gore, J., Patfield, S., Holmes, K., Gruppetta, M., Smith, M., Lloyd, A., ..., Fray, L. (in press). When higher education is possible but not desirable: Widening participation and the aspirations of Australian Indigenous school students. Australian Journal of Education.

Harrison, N. (2004). The reproduction of historical relations in the crosscultural classroom at university. Australian Journal of Education, 48, 282-294. doi:10.1177/000494410404800306.

Harwood, V., McMahon, S., O’Shea, S., Bodkin-Andrews, G., \& Priestly, A. (2015). Recognising aspiration: The AIME program's effectiveness in inspiring Indigenous young people's participation in schooling and opportunities for further education and employment. Australian Educational Resarcher, 42, 217-236. doi:10.1007/s13384-015-0174-3.

Hillman, K. (2005). The first year experience: The transition from secondary school to university and TAFE in Australia. Retrieved April 19, 2016 from http://research.acer.edu.au/lsay_research/44. 
Hossain, D., Gorman, D., Williams-Mozely, J., \& Garvey, D. (2008). Bridging the gap: Indentifying needs and aspirations of Indigenous students to facilitate their entry into university. The Australian Journal of Indigenous Education, 37, 9-17. doi:10.1375/s1326011100000053.

Howlett, C., Seini, M., Matthews, C., Dillon, B., \& Hauser, V. (2008). Retaining Indigenous students in tertiary education: Lessons from the Griffith School of Environment. The Australian Journal of Indigenous Education, 37, 18-27. Retrieved March 22, 2016 from https://www.cambridge.org/core/ services/aop-cambridge-core/content/view/S1326011100016057.

Kelly, H., Robinson, A., Drysdale, M., Chesters, J., Faulkner, S., Ellender, I., \& Turnbull, L. (2009). 'It's not about me, it's about the community': Culturally relevant health career promotion for Indigenous students in Australia. The Australian Journal of Indigenous Education, 38, 19-26. Retrieved March 24, 2016 from http://search.informit.com.au.ezproxy.newcastle.edu.au/fullText;res=AEIPT; $\mathrm{dn}=$ 181060 ?.

Kinnane, S., Wilks, J., Wilson, K., Hughes, T., \& Thomas, S. (2014). 'Can't be what you can't see': The transition of Aboriginal and Torres Strait Islander students to higher education. Retrieved April 19, 2016 from http://www.nd.edu.au/_data/assets/pdf_file/0018/122364/OLT-ID-SI11-2138-Lit-RevFinal-14-March-2014.pdf.

Kippen, S., Ward, B., \& Warren, L. (2006). Enhancing Indigenous participation in higher education health courses in rural Victoria. The Australian Journal of Indigenous Education, 35, 1-10. doi:10. $1017 / \mathrm{s} 1326011100004117$.

Lefebvre, C., Manheimer, E., \& Glanville, J. (2008). Chapter 6: Searching for studies. In J. P. T. Higgins \& S. Green (Eds.), Cochrane handbook for systematic reviews of interventions (pp. 95-150). Chichester: Wiley-Blackwell.

Lette, H., Tursan D’Espaignet, E., Slack-Smith, L., Kerry Hunt, K., \& Nannup, J. (2009). Indigenous mothers' aspirations for their children in Perth, Western Australia. The Australian Journal of Indigenous Education, 38, 65-73. Retrieved March 16, 2016 from https:/www.cambridge.org/core/ services/aop-cambridge-core/content/view/890744937D0DB8EC05533693346ACFD3/ S1326011100000600a.pdf/indigenous-mothers-aspirations-for-their-children-in-perthwestern-australia-the-value-of-education-and-schooling.pdf.

Mander, D. J., Cohen, L., \& Pooley, J. A. (2015). 'If I wanted to have more opportunities and go to a better school, I just had to get used to it': Aboriginal students' perceptions of going to boarding school in Western Australia. The Australian Journal of Indigenous Education, 44, 26-36. doi:10. 1017/jie.2015.3.

Mills, J., Felton-Busch, C., Park, T., Maza, K., Mills, F., Ghee, M., et al. (2014). Supporting Australian Torres Strait Islander and Aboriginal nursing students using mentoring circles: An action research study. Higher Education Research \& Development, 33, 1136-1149. doi:10.1080/07294360.2014. 911262.

Mission Australia. (2014). Indigenous aspirations: Employment \& educational opportunities for Aboriginal \& Torres Strait Islander youth. Sydney: Author. Retrieved February 9, 2016 from http://www.voced.edu.au/content/ngv\%3A65192.

Mohajer, N., Bessarab, D., \& Earnest, J. (2009). There should be more help out here! A qualitative study of the needs of Aboriginal adolescents in rural Australia. Rural and Remote Health, 9, 1-11. Retrieved April 27, 2016 from http://www.rrh.org.au/publishedarticles/article_print_1137.pdf.

Morgan, D. (2001). Indigenous education: Factors affecting students' decisions to continue or withdraw from tertiary studies at Flinders University. International Education Journal, 2, 233-239. Retrieved April 19, 2016 from http://ehlt.flinders.edu.au/education/iej/articles/v2n4/MORGAN/PAPER.PDF.

Naylor, R., Baik, C., \& James, R. (2013). A critical interventions framework for advancing equity in Australian higher education. Canberra: Department of Industry, Innovation, Climate Change, Science, Research and Tertiary Education. Retrieved September 30, 2016 from https://www.ncsehe. edu.au/publications/critical-interventions-framework/.

Nelson, A., \& Hay, P. J. (2010). 'I don't want to grow up and not be smart': Urban Indigenous young people's perceptions of school. The Australian Journal of Indigenous Education, 39, 54-64. Retrieved March 3, 2016 from http://search.informit.com.au/documentSummary; $\mathrm{dn}=$ 633615169249111;res=IELIND.

O'Bryan, M. (2015). Compelled to innovate: Facilitating partnerships in cross-cultural education. UNESCO Observatory Multi-Disciplinary Journal in the Arts, 4. Retrieved March 31, 2017 from http://education.unimelb.edu.au/_data/assets/pdf_file/0010/1391653/006_OBRYAN_V2.pdf. 
O'Shea, S., Harwood, V., Kervin, L., \& Humphry, N. (2013). Connection, challenge, and change: The narratives of university students mentoring young Indigenous Australians. Mentoring \& Tutoring: Partnership in Learning, 21, 392-411. doi:10.1080/13611267.2013.855863.

Oliver, R., Grote, E., Rochecouste, J., \& Dann, T. (2015). Indigenous student perspectives on support and impediments at university. The Australian Journal of Indigenous Education, 45, 23-35. doi:10.1017/ jie.2015.16.

Oliver, R., Rochecouste, J., Bennell, D., Anderson, R., Cooper, I., Forrest, S., et al. (2013). Understanding Australian Aboriginal tertiary student needs. The International Journal of Higher Education, 2, 52-64. doi:10.5430/ijhe.v2n4p52.

Page, S., \& Asmar, C. (2008). Beneath the teaching iceberg: Exposing the hidden support dimensions of Indigenous academic work. The Australian Journal of Indigenous Education, 37, 109-117. Retrieved April 13, 2016 from http://search.informit.com.au.ezproxy.newcastle.edu.au/fullText;res= AEIPT; dn=171539?.

Parker, P., Bodkin-Andrews, G., Marsh, H., Jerrim, J., \& Schoon, I. (2015). Will closing the achievement gap solve the problem? An analysis of primary and secondary effects for Indigenous university entry. Journal of Sociology, 51, 1085-1102. Retrieved March 5, 2017 from http://journals.sagepub. com/doi/abs/10.1177/1440783313498946?journalCode=josb.

Parkes, A., McRae-Williams, E., \& Tedmanson, D. (2015). Dreams and aspirations of mobile young Aboriginal Australian people. Journal of Youth Studies, 18, 763-776. doi:10.1080/13676261.2014. 992314.

Pechenkina, E., \& Anderson, I. (2011). Background paper on Indigenous Australian higher education: Trends, initiatives and policy implications. Retrived March 7, 2017 from https://sydney.edu.au/ documents/about/higher_education/2011/20110930\%20IndigenousHigherEducationReviewReseachPaper.pdf.

Pechenkina, E., Kowal, E., \& Paradies, Y. (2011). Indigenous Australian students' participation rates in higher education: Exploring the role of universities. The Australian Journal of Indigenous Education, 40, 59-68. doi:10.1375/ajie.40.59.

Pham, M. T., Rajić, A., Greig, J. D., Sargeant, J. M., Papadopoulos, A., \& McEwen, S. A. (2014). A scoping review of scoping reviews: Advancing the approach and enhancing the consistency. Research Synthesis Methods, 5, 371-385. doi:10.1002/jrsm.1123.

Plater, S. (2013). 'For the life of me, I can't see why those students were let go on so long': Educating the educators, Aboriginal and Torres Strait Islander-style. The Australian Journal of Indigenous Education, 41, 156-161. doi:10.1017/jie.2012.24.

Rahman, K. (2010). Addressing the foundations for improved Indigenous secondary student outcomes: A South Australian qualitative study. The Australian Journal of Indigenous Education, 39, 65-76. Retrieved May 4, 2016 from http://search.informit.com.au.ezproxy.newcastle.edu.au/fullText;res= AEIPT; $\mathrm{dn}=185425 ?$.

Rigby, W., Duffy, E., Manners, J., Latham, H., Lyons, L., Crawford, L., et al. (2010). Closing the gap: Cultural safety in Indigenous health education. Contemporary Nurse, 37, 21-30. doi:10.5172/conu. 2011.37.1.021.

Rochecouste, J., Oliver, R., \& Bennell, D. (2014). Is there cultural safety in Australian universities? The International Journal of Higher Education, 3, 153-166. doi:10.5430/ijhe.v3n2p153.

Santoro, N. (2010). 'If it weren't for my mum...': The influence of Australian Indigenous mothers on their children's aspirations to teach. Gender and Education, 22, 419-429. doi:10.1080/ 09540250903289915.

Senior, K. A., \& Chenhall, R. D. (2012). Boyfriends, babies and basketball: Present lives and future aspirations of young women in a remote Australian Aboriginal community. Journal of Youth Studies, 15, 369-388. doi:10.1080/13676261.2012.663890.

Shah, M., \& Widin, J. (2010). Indigenous students' voices: Monitoring Indigenous student satisfaction and retention in a large Australian university. Journal of Institutional Research, 15, $28-41$. Retrieved February 5, 2016 from http://eric.ed.gov/?id=EJ1094105.

Sharrock, P., \& Lockyer, H. (2008). One to one and face to face: A community based higher education support strategy retaining Indigenous Australian university students. The Australian Journal of Indigenous Education, 37, 28-39.

Sikora, J., \& Biddle, N. (2015). How gendered is ambition? Educational and occupational plans of Indigenous youth in Australia. International Journal of Educational Development, 42, 1-13. doi:10. 1016/j.ijedudev.2015.02.011. 
Sonn, C., Bishop, B., \& Humphries, R. (2000). Encounters with the dominant culture: Voices of Indigenous students in mainstream higher education. Australian Psychologist, 35, 128-135. doi:10. $1080 / 00050060008260334$.

Toombs, M., \& Gorman, D. (2010). Why do Indigenous students succeed at university? Aboriginal \& Islander Health Worker Journal, 34, 14-16. Retrieved March 3, 2016 from http://search.informit. com.au/documentSummary; $\mathrm{dn}=650949518709372 ;$ res=IELAPA.

Tricco, A. C., Lillie, E., Zarin, W., O’Brien, K., Colquhoun, H., Kastner, M., et al. (2016). A scoping review on the conduct and reporting of scoping reviews. BMC Medical Research Methodology, 16, 1-10. doi:10.1186/s12874-016-0116-4.

Trudgett, M. (2009). Build it and they will come: Building the capacity of Indigenous units in universities to provide better support for Indigenous Australian postgraduate students. The Australian Journal of Indigenous Education, 38, 9-18. Retrieved May 3, 2016 from http://search.informit.com.au.ezproxy. newcastle.edu.au/fullText;res=AEIPT; $\mathrm{dn}=181059$ ?.

Turnbull, M. (2014). Creating an accessible and effective pathway for regional and isolated Aboriginal and Torres Strait Islander people to tertiary study using block-release study mode. Retrieved March 4, 2016 from http://www.voced.edu.au/content/ngv\%3A61514.

Usher, K., Lindsay, D., Miller, M., \& Miller, A. (2005). Challenges faced by Indigenous nursing students and strategies that aided their progress in the course: A descriptive study. Contemporary Nurse, 19, 17-31. doi:10.5172/conu.19.1-2.17.

Walker, R., Scrine, C., \& Shepherd, C. (2008). Job aspirations of young Indigenous people in the East Kimberley: Making new tracks. Retrieved February 18, 2016 from http://wunan.org.au/pdf/job_ aspirations_2008.pdf.

Walter, M. M. (2010). The politics of data: How the Australian Statistical Indigene is constructed. International Journal of Critical Indigenous Studies, 3, 45-51. Retrieved March 16, 2017 from http://www.isrn.qut.edu.au/publications/internationaljournal/documents/Final__MaggieWalter_ IJCIS.pdf.

Walter, M. M. (2015). The vexed link between social capital and social mobility for Aboriginal and Torres Strait Islander people. Australian Journal of Social Issues, 50, 69-88. doi:10.1002/j.18394655.2015.tb00335.x.

West, R., Usher, K., Foster, K., \& Stewart, L. (2014). Academic staff perceptions of factors underlying program completion by Australian Indigenous nursing students. The Qualitative Report, 19, 1-19. Retrieved February 26, 2016 from http://search.ebscohost.com/login.aspx direct=true $\& \mathrm{db}=$ sih\&AN=95258918\&site=ehost-live.

Whitty, G., Hayton, A., \& Tang, S. (2015). Who you know, what you know and knowing the ropes: A review of evidence about access to higher education institutions in England. Review of Education, 3, 27-67. doi:10.1002/rev3.3038.

Jennifer Gore is a Professor in the School of Education and Director of the Teachers and Teaching Research Centre at the University of Newcastle. In addition to a program of research on student aspirations, she is currently leading a research agenda focused on improving student outcomes and supporting teacher professional development through an innovative approach called Quality Teaching Rounds.

Sally Patfield is a Ph.D. candidate and research assistant in the Teachers and Teaching Research Centre at the University of Newcastle. With an interest in equity research and practice, her Ph.D. investigates the aspirations for university of school students who would be the first in their families to enter higher education.

Leanne Fray is a postdoctoral fellow at the University of Newcastle in the Teachers and Teaching Research Centre. She has extensive experience in qualitative research and has previously worked on research projects across such disciplines as health, education, and social science. Her research interests include improving student access and participation in higher education.

Kathryn Holmes is a Professor of Education at Western Sydney University. With a background in mathematics education, her current research focuses on the application of technology in education, 
increasing participation in STEM disciplines, and improving quality, equity, and access in schools and higher education.

Maree Gruppetta is an Associate Professor and currently head of the Umulliko Research Centre within the Wollotuka Institute and of an Aboriginal and Torres Strait Islander Research and Innovation Cluster at the University of Newcastle. A Guyinbaraay woman, she has taught extensively in primary and secondary classrooms. Her research over the last decade has focused on Aboriginal Education and Health.

Adam Lloyd is a postdoctoral fellow in the Teachers and Teaching Research Centre at the University of Newcastle with a diverse background in engineering, mathematics education, and research on child lifestyle behaviours. With a particular interest in STEM, his current research focuses on Quality Teaching, student aspirations in the middle years of schooling, and improving equity in education.

Maxwell Smith is a Professor in the School of Education at the University of Newcastle and a founding member of the Teachers and Teaching Research Centre. With expertise in complex quantitative analysis, his research interests extend from child development and pedagogy to measurement and evaluation in education.

Treesa Heath is a Kamilaroi woman, former research assistant in the University of Newcastle's Teachers and Teaching Research Centre and currently holds a position as Indigenous New Career Academic with the Wollotuka Institute. Currently undertaking a Ph.D. in the application of Indigenous research methodologies in Australia, she is driven to support the self-determination of Indigenous Peoples globally. 